\title{
Size, shape and spatial arrangement of mega-scale glacial lineations from a large and diverse dataset
}

\author{
Matteo Spagnolo, ${ }^{1 *}$ Chris D. Clark, ${ }^{2}$ Jeremy C. Ely, ${ }^{2}$ Chris R. Stokes, ${ }^{3}$ John B. Anderson, ${ }^{4}$ Karin Andreassen, ${ }^{5}$ \\ Alastair G. C. Graham ${ }^{6}$ and Edward C. King \\ ${ }^{1}$ School of Geosciences, University of Aberdeen \\ ${ }^{2}$ Geography Department, University of Sheffield \\ ${ }^{3}$ Geography Department, Durham University \\ ${ }^{4}$ Department of Earth Science, Rice University \\ ${ }^{5}$ Department of Geology, University of Tromso \\ ${ }^{6}$ Department of Geography, University of Exeter \\ 7 Ice Sheets Programme, British Antarctic Survey
}

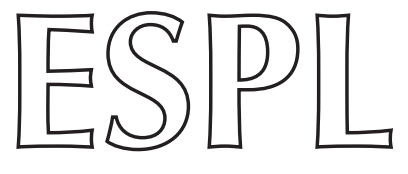

ABSTRACT: Mega-scale glacial lineations (MSGLs) are a characteristic landform on ice stream beds. Solving the puzzle of their formation is key to understanding how ice interacts with its bed and how this, in turn, influences the dynamics of ice streams. However, a comprehensive and detailed characterization of this landform's size, shape and spatial arrangement, which might serve to test and refine formational theories, is largely lacking. This paper presents a detailed morphometric analysis and comparison of 4043 MSGLs from eight palaeo-ice stream settings: three offshore (Norway and Antarctica), four onshore (Canada), and one from under a modern ice stream in West Antarctica. The length of MSGLs is lower than previously suggested (mode 1000-2000 m; median $2892 \mathrm{~m}$ ), and they initiate and terminate at various locations on an ice stream bed. Their spatial arrangement reveals a pattern that is characterized by an exceptional parallel conformity ( $80 \%$ of all mapped MSGLs have an azimuth within $5^{\circ}$ from the mean values), and a fairly constant lateral spacing (mode 200-300 m; median 330 m), which we interpret as an indication that MSGLs are a spatially self-organized phenomenon. Results show that size, shape and spatial arrangement of MSGLs are consistent both within and also generally between different ice stream beds. We suggest this results from a common mechanism of formation, which is largely insensitive to local factors. Although the elongation of MSGLs (mode 6-8; median 12.2) is typically higher than features described as drumlins, these values and those of their width (mode 100-200 m; median $268 \mathrm{~m}$ ) overlap, which suggests the two landforms are part of a morphological continuum and may share a similar origin. We compare their morphometry with explicit predictions made by the groove-ploughing and rilling instability theories of MSGL formation. Although the latter was most compatible, neither is fully supported by observations. (c) 2014 The Authors. Earth Surface Processes and Landforms Published by John Wiley \& Sons Ltd.

KEYWORDS: MSGL; glacial bedform; ice stream; morphometry

\section{Introduction}

Outlet glaciers and ice streams are fast flowing (up to $1000 \mathrm{~s} \mathrm{~m}$ per year) corridors of ice within ice sheets (Bennett, 2003). They are the main arteries through which ice sheets lose mass, accounting for up to $90 \%$ of Antarctic discharge, for example (Morgan et al., 1982; Rignot et al., 2011). Ice streams are also dynamic and can widen, migrate or shut down on decadal timescales (Conway et al., 1999; Hulbe and Fahnestock, 2004). Thus, their operation is a key control on ice-sheet mass balance at a range of time-scales. A hierarchy of controls are thought to influence the location of ice streams (Winsborrow et al., 2010), but in most cases, their dynamic behaviour is thought to be influenced by a soft sedimentary bed (Alley et al., 1986; Engelhardt and Kamb, 1997; Tulaczyk et al.,
2001). Unfortunately, direct access to the ice-bed interface has only been achieved at a handful of sites along the Siple Coast of West Antarctica (Engelhardt and Kamb, 1997) via costly drilling, which while valuable, provides spatially limited 'point' data. Geophysical techniques provide a valid alternative (Smith and Murray, 2009), but the logistics remain challenging and such techniques have been applied only to a few Antarctic sites, with grids necessarily limited to small $\left(10 \mathrm{~s} \mathrm{~km}^{2}\right.$ ) areas (King et al., 2009). In contrast, there is an abundance of relatively well preserved palaeo ice stream beds (Winsborrow et al., 2004), which are a useful proxy for the study of ice-bed interactions and which permit easier access to the landforms and sediments created by ice streams. Indeed, there are numerous studies that provide a detailed characterization of palaeo-ice stream beds from 
onshore and offshore regions (see reviews in Stokes and Clark, 2001; Livingstone et al., 2012).

Mega-scale glacial lineations (MSGLs) are extremely elongated ridges that maintain a parallel conformity over lengths of 10 s of $\mathrm{km}$ (Clark, 1993). MSGLs have been identified for many decades (Lemke, 1958), but were first formally recognized and named by Clark (1993) from Landsat imagery of Canada. Based primarily on their great length, and parallel conformity, they were hypothesized to have formed beneath fast flowing ice streams or surges (Clark, 1993, 1994). Such a proposal gained acceptance after numerous discoveries of MSGLs on the Antarctic continental shelf (Shipp et al., 1999; Canals et al., 2000; Wellner et al., 2001) in positions proximal to present-day ice streams. This association has now been verified by radar profiling of the bed of the modern Rutford Ice Stream, West Antarctica (Smith et al., 2007; King et al., 2009) where MSGLs were imaged and shown to evolve (e.g. evidence of both erosion and deposition) over a 7 year period. As MSGLs have been found in front of and beneath ice streams and evolving during fast ice flow, they are now widely considered to be the key landform signature for identifying palaeo-ice streams (Stokes and Clark, 1999, 2003; Jakobsson et al., 2005; Ottesen et al., 2005b; Stoker and Bradwell, 2005; Przybylski, 2008). The link between MSGLs and ice streams has also helped decipher the history of sediment sequences and palaeo geography of continental shelves that are relevant to petroleum and gas exploration (Sejrup et al., 2005; Nygård et al., 2007). Furthermore, MSGLs have been identified in ancient (440 million years) sandstones in Africa (Moreau et al., 2005) and, more controversially, on Mars (Lucchitta, 2001; Hubbard et al., 2011).

Despite the importance of MSGLs to our understanding of subglacial processes under ice streams, their mechanism of formation is yet to be resolved, although several different ideas have been proposed (Clark, 1993; Tulaczyk et al., 2001; Clark et al., 2003; Schoof and Clarke, 2008; Shaw et al., 2008; Fowler, 2010). Indeed, the formation of MSGLs is likely to be important for answering fundamental questions regarding the mechanisms of ice stream flow, such as the role of basal sliding versus subglacial till deformation and how roughness elements evolve and modulate ice stream motion. It has been hypothesized, for example, that enhanced flow within ice streams might be caused by: (i) sliding across the surface of a soft sedimentary bed (Engelhardt and Kamb, 1997); (ii) deforming soft sediments at depths of a few centimetres to several metres (Alley et al., 1986), or (iii) a combination of the two that includes a component of ploughing (Tulaczyk et al., 2001).

Attempts to convert these hypotheses into physically-based numerical models are ongoing (Schoof, 2002; Bougamont et al., 2011), and this is considered a fundamental requirement for constraining predictions of the consequences of global climate change on ice stream dynamics (IPCC, 2007). Thus, the next generation of numerical models should account for the production of MSGLs, and be validated through their ability to reproduce MSGLs of the correct size and shape. A prerequisite for this, however, is a quantitative characterization of MSGLs based on a large and diverse dataset, similar to that which has recently been undertaken for drumlins (Clark et al., 2009; Hess and Briner, 2009; Spagnolo et al., 2010, 2011, 2012). This paper presents the results of detailed morphometric analysis of a sizeable dataset (4043) of MSGLs mapped from eight different locations around the world, both onshore and offshore, and both in palaeo and present-day ice stream bed settings. The aim is to provide an inventory of MSGL metrics and a robust dataset to both test and develop theories of MSGL formation.

\section{A Summary of Previous Work on the 'Metrics' of MSGLs}

MSGLs were initially distinguished and named as a separate type of subglacial landform because of their extraordinary length, well exceeding that of drumlins, flutes and megaflutes, but also because of their straight crestline and repetitive parallel arrangement (Clark, 1993). Using Canadian examples, Clark (1993) described them as typically characterized by a length of $8-70 \mathrm{~km}$, width of $200-1300 \mathrm{~m}$ and spacing of $300-5000 \mathrm{~m}$. Since then, numerous studies in different parts of the world have expanded the range of MSGL metrics: lengths of $<1-180 \mathrm{~km}$, widths of 39-5000 m, heights of 1-100 m, elongations (length L/width W) of 2-200:1 and across-flow spacings of 50-5104 m (Table I). However, most previously published work is restricted to qualitative or semi-quantitative descriptions, often only citing minimum and maximum values and, more rarely, estimating mean values, typically expressed as a range or a 'lower than' figure (Table I and references therein). Statistical descriptions of large sample sizes ( $>100$ bedforms) are extremely rare (Graham et al., 2009; Livingstone et al., 2013; Stokes et al., 2013), and very few studies compare data from different ice stream beds (Ottesen et al., 2005b).

\section{Methods}

The MSGL database was assembled from a total of eight study areas (Table II; Figure 1) that have been previously identified as ice stream beds with abundant MSGLs (Winsborrow et al., 2004, 2012; Graham et al., 2009; King et al., 2009; Brown et al., 2011; Jakobsson et al., 2011, 2012). Although MSGLs have previously been reported from these regions, they have never been systematically mapped or analyzed in detail.

\section{Datasets}

Offshore, three palaeo ice stream beds were studied: two located beneath the Amundsen Sea, Antarctica (Pine Island, and Getz), and one under the Barents Sea, off northern Norway (Håkerringjdupet). These marine datasets were chosen because of the availability of high resolution 3D terrain data (Table II, Figure 1(A), (B), (C), (E)).

Pine Island trough comprises two distinct sets of MSGLs belonging to distinct ice streaming events and which are separated by a grounding zone wedge (Jakobsson et al., 2012). In this paper, the northernmost set has been called 'Pine Island $\mathrm{N}^{\prime}$, and the southernmost 'Pine Island $\mathrm{S}$ '. Together, they cover about $40 \%$ of the entire Pine Island trough length, and are located in its middle to outer portion. The area is covered by terrain data with horizontal resolution of $20 \mathrm{~m}$ and vertical resolution of $\sim 2 \mathrm{~m}$, collected using a hull-mounted Kongsberg $12 \mathrm{kHz}$ EM122 multibeam echo-sounder. The Getz area comprises one set of MSGLs from the inner to middle shelf part of the ice stream pathway. The middle-to-outer shelf is either iceberg scoured or unsurveyed. The ice stream trough (from present-day ice-shelf front to the continental shelf break) is $\sim 280 \mathrm{~km}$ long, and the MSGLs used in this study cover a $\sim 65 \mathrm{~km}$ long portion of it (providing data across most of the ice stream width). The area has terrain data which was collected in 2006 by hull-mounted Kongsberg EM120 and Atlas Hydrosweep DS-2 multibeam swath systems. The combined data are gridded at $30 \mathrm{~m}$ bin size, well within the capability of both systems at these shelf water depths $(\sim 700 \mathrm{~m})$. Depth resolution for the echo-sounders is $0.1 \mathrm{~m}$ for both systems and vertical resolution of the gridded output is $\leq \sim 2 \mathrm{~m}$. MAREANO 
Table I. Metrics of MSGLs as reported in previous papers (in order of publication year). Note that most refer to minimum and maximum values and when mean values are indicated, these are often estimates ('es' on the table next to the values)

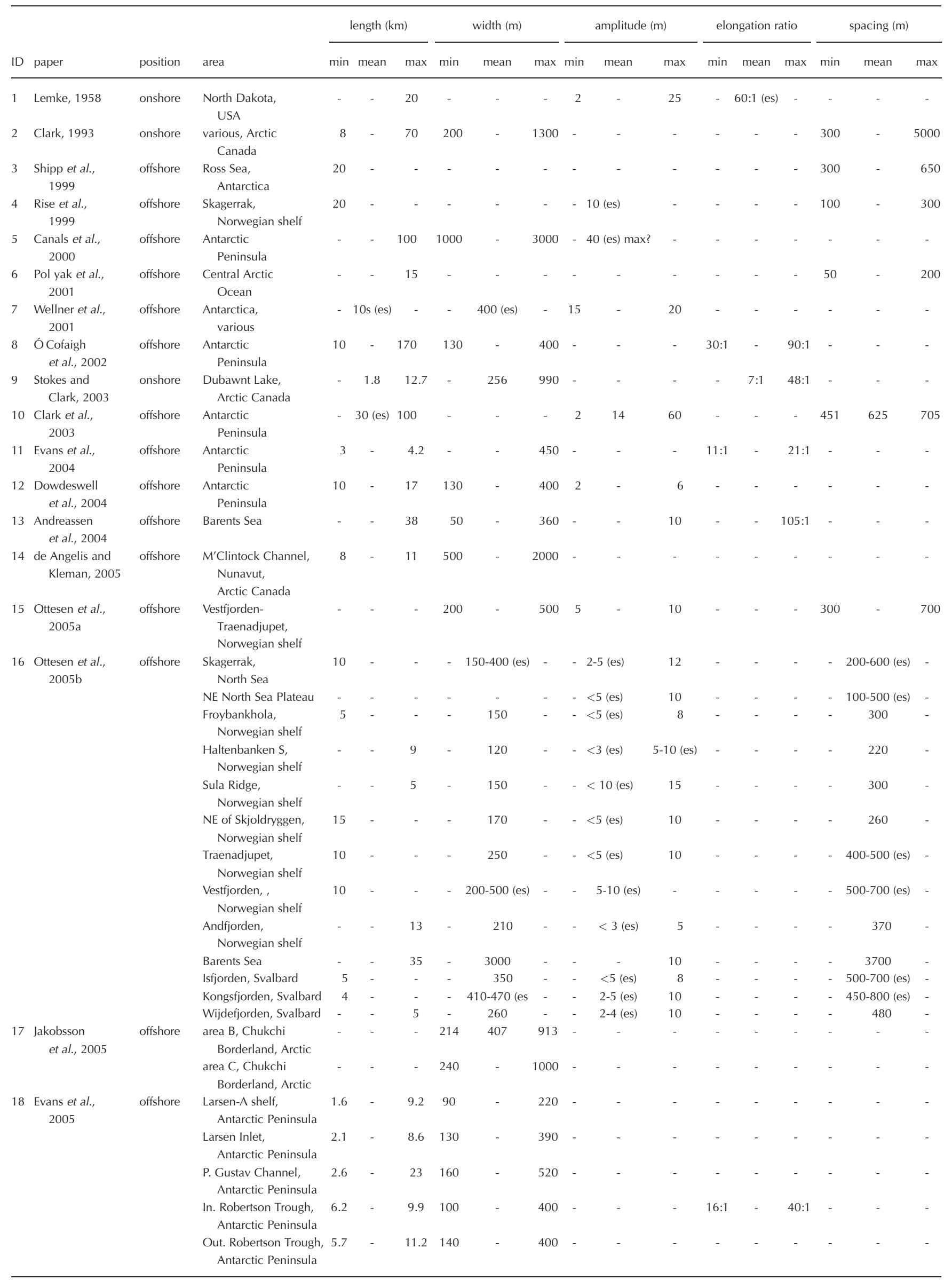


Table 1. (Continued)

\begin{tabular}{|c|c|c|c|c|c|c|c|c|c|c|c|c|c|c|c|c|c|c|}
\hline \multirow[b]{2}{*}{ ID } & \multirow[b]{2}{*}{ paper } & \multirow[b]{2}{*}{ position } & \multirow[b]{2}{*}{ area } & \multicolumn{3}{|c|}{ length (km) } & \multicolumn{3}{|c|}{ width (m) } & \multicolumn{3}{|c|}{ amplitude (m) } & \multicolumn{3}{|c|}{ elongation ratio } & \multicolumn{3}{|c|}{ spacing (m) } \\
\hline & & & & $\min$ & mean & $\max$ & $\min$ & mean & $\max r$ & $\min$ & mean & $\max$ & $\min$ & mean & $\max$ & $\min$ & mean & $\max$ \\
\hline 19 & $\begin{array}{l}\text { Ó Cofaigh } \\
\text { et al., } 2005\end{array}$ & offshore & Antarctic Peninsula & 10 & - & 22 & - & - & - & 2 & 3 & 8 & - & - & - & 150 & 305 & 550 \\
\hline 20 & $\begin{array}{l}\text { Heroy and } \\
\text { Anderson, } 2005\end{array}$ & offshore & Antarctic Peninsula & - & - & 22 & - & - & - & 10 & - & 20 & - & - & $80: 1$ & 200 & 300 & 600 \\
\hline & 2006 & & various Antarctica & - & - & - & - & - & - & - & - & - & - & - & - & & & \\
\hline 22 & $\begin{array}{l}\text { Evans et al., } \\
2006\end{array}$ & offshore & $\begin{array}{l}\text { Pine Island } \\
\text { Bay, Antarctica }\end{array}$ & 6.8 & - & 10 & 160 & - & 420 & - & - & - & $18: 1$ & - & $60: 1$ & - & - & - \\
\hline 23 & $\begin{array}{l}\text { Domack } \\
\text { et al., } 2006\end{array}$ & offshore & Antarctic Peninsula & 30 & - & 120 & - & - & - & - & 25 (es) & - & - & - & - & - & 2000 (es) & - \\
\hline 24 & $\begin{array}{l}\text { McMullen } \\
\text { et al., } 2006\end{array}$ & offshore & $\begin{array}{l}\text { Mertz Trough, } \\
\text { E Antarctica }\end{array}$ & 14 & - & 20 & - & 500 (es) & - & - & 20 (es) & - & - & - & - & 1000 & - & 1500 \\
\hline 25 & $\begin{array}{l}\text { Andreassen } \\
\text { et al., } 2007\end{array}$ & offshore & $\begin{array}{c}\text { Barents Sea } 180500 \\
50004985: 1\end{array}$ & - & - & 180 & 500 & - & 5000 & 4 & - & 9 & - & - & $85: 1$ & - & - & - \\
\hline 26 & $\begin{array}{l}\text { Graham et al., } \\
2007\end{array}$ & offshore & $\begin{array}{l}\text { Witch Ground Basin, } \\
\text { North Sea }\end{array}$ & 5 & - & 20 & 50 & - & 120 & - & 10-12 (es) & - & - & $50: 1$ (es) & ) 150:1 & 100 & - & - \\
\hline 27 & $\begin{array}{l}\text { Ottesen et al., } \\
2007\end{array}$ & offshore & Svalbard & $<1$ & - & 10 & - & - & - & - & - & 15 & - & - & - & 100 & - & 2000 \\
\hline \multirow[t]{3}{*}{28} & $\begin{array}{l}\text { Andreassen } \\
\text { et al., } 2008\end{array}$ & offshore & $\begin{array}{c}\text { Bjørnøyrenna, SW } \\
\text { Barents Sea, }\end{array}$ & - & - & 180 & 2000 & - & 5000 & - & - & 10 & - & - & $40: 1$ & - & - & - \\
\hline & & & $\begin{array}{l}\text { Ingøydjupet, SW } \\
\text { Barents Sea, }\end{array}$ & - & - & 120 & 500 & - & 3500 & 4 & - & 5 & - & - & $33: 1$ & - & - & - \\
\hline & & & $\begin{array}{c}\text { Djuprenna, SW } \\
\text { Barents Sea }\end{array}$ & - & - & 180 & - & - & 800 & - & - & 9 & - & - & $85: 1$ & - & - & - \\
\hline 29 & $\begin{array}{l}\text { Ottesen et al., } \\
2008\end{array}$ & offshore & Svalbard & - & - & 1 & - & - & 200 & - & - & 5 & - & - & - & - & - & - \\
\hline 30 & $\begin{array}{l}\text { Ottesen et al., } \\
2008 \mathrm{~b}\end{array}$ & offshore & N Norwegian shelf & 3 & - & 40 & 200 & - & 1200 & 1 & - & 30 & $10: 1$ & - & - & 250 & - & 3000 \\
\hline 31 & $\begin{array}{l}\text { Engels et al., } \\
2008\end{array}$ & offshore & Arctic Ocean & - & - & 10 & - & 50 (es) & - & - & - & - & - & - & $200: 1$ & - & - & - \\
\hline \multirow[t]{3}{*}{33} & $\begin{array}{l}\text { Graham et al., } \\
2009\end{array}$ & offshore & $\begin{array}{c}\text { Getz B, Amundsen } \\
\text { Sea, Antarctica }\end{array}$ & 1 & - & 20 & 100 & - & 500 & - & - & 50 & - & - & $45: 1$ & - & - & - \\
\hline & & & $\begin{array}{c}\text { Getz A, Amundsen } \\
\text { Sea, Antarctica }\end{array}$ & 1 & - & 15 & 100 & - & 400 & 10 & - & 100 & $5: 1$ & - & $70: 1$ & - & - & - \\
\hline & & & $\begin{array}{l}\text { Mid/outer shelf, } \\
\text { Amundsen } \\
\text { Sea, Antarctica }\end{array}$ & 6 & - & 38 & 131 & - & 451 & 2 & 5-10 (es) & 18 & $25: 1$ & - & $140: 1$ & 80 & - & $>300$ \\
\hline 34 & $\begin{array}{l}\text { Ross et al., } \\
2011\end{array}$ & both & $\begin{array}{l}\text { Coats Island, } \\
\text { Hudson Bay, } \\
\text { Canada }\end{array}$ & - & - & 20 & - & $600-800$ (es) & - & - & - & - & - & $28: 1$ (es) & - & - & - & - \\
\hline 35 & $\begin{array}{l}\text { Rebesco et al., } \\
\quad 2011\end{array}$ & offshore & $\begin{array}{l}\text { Kveithola trough, } \\
\text { Barents Sea }\end{array}$ & - & - & 8 & 100 & - & 600 & - & - & 15 & - & - & $10: 1$ & - & - & - \\
\hline 36 & $\begin{array}{l}\text { Ruther et al., } \\
\quad 2011\end{array}$ & offshore & $\begin{array}{l}\text { Bjornoyrenna, } \\
\text { Barents Sea }\end{array}$ & 20 & - & 40 & 1500 & - & 4000 & 5 & - & 10 & - & - & - & - & 5000 (es) & - \\
\hline 37 & $\begin{array}{l}\text { Larter et al., } \\
\quad 2012\end{array}$ & offshore & $\begin{array}{r}\text { Weddell Sea, } \\
\text { Antarctica }\end{array}$ & - & - & 18 & - & - & - & 2 & - & 12 & - & - & $60: 1$ & 250 & - & 2500 \\
\hline 38 & $\begin{array}{l}\text { Winsborrow } \\
\text { et al., } 2012\end{array}$ & offshore & SW Barents Sea & 0.3 & 2.2 & 20 & 500 & - & 1000 & - & - & - & - & - & - & - & - & - \\
\hline 39 & $\begin{array}{l}\text { Greenwood } \\
\text { et al., } 2012\end{array}$ & offshore & $\begin{array}{l}\text { Ross Sea, } \\
\text { Antarctica }\end{array}$ & 0.3 & 1 & 3.2 & - & - & - & 2 & - & 5 & - & - & - & - & - & - \\
\hline \multirow[t]{2}{*}{40} & $\begin{array}{l}\text { Stolldorf } \\
\text { et al., } 2012\end{array}$ & offshore & $\begin{array}{l}\text { Ronne Trough, } \\
\text { Weddell Sea, } \\
\text { Antarctica }\end{array}$ & 12 & - & - & - & - & - & 4 & - & 10 & $100: 1$ & - & - & 200 & - & 500 \\
\hline & & & $\begin{array}{l}\text { HughesTrough, } \\
\text { Weddell Sea, } \\
\text { Antarctica }\end{array}$ & 22 & - & - & - & - & - & 4 & - & 7 & $50: 1$ & - & - & 300 & - & 600 \\
\hline 41 & $\begin{array}{l}\text { Stokes et al., } \\
2013\end{array}$ & onshore & $\begin{array}{l}\text { Dubawnt Lake, } \\
\text { Arctic Canada }\end{array}$ & 0.2 & 0.9 & 20.1 & 39 & 117 & 553 & - & - & - & $2: 1$ & $9: 1$ & 149:1 & - & - & - \\
\hline
\end{tabular}

(www.mareano.no) multibeam data, collected by the Norwegian Hydrographic Service (horizontal resolution of $5 \mathrm{~m}$, vertical resolution of $\sim 5 \mathrm{~m}$ ), were used in the Håkjerringdjupet area. The area comprises one main set of MSGLs (Winsborrow et al., 2012) covering about $30 \%$ of the entire palaeo ice stream.
Four previously recognized palaeo-ice stream beds were studied from onshore settings (Winsborrow et al., 2004; Brown et al., 2011) and selected for mapping due to the excellent preservation of MSGLs in these regions and the lack of cross-cutting landform relationships (Table II; Figure 1(F), (G), (H), (I)). All 
four are situated in north-west Canada, where ice streaming is thought to have contributed to the low ice surface profile and rapid retreat of the Laurentide Ice Sheet (Beget, 1987; Brown et al., 2011). The areas are covered by Landsat ETM+and SPOT satellite images with a horizontal resolution of 15 and $10 \mathrm{~m}$, respectively. Unlike their onshore counterparts, these palaeo ice streams are not situated in topographic troughs, thus making it difficult to quantify what percentage of the original ice stream bed is covered by the analyzed MSGLs.

MSGLs from the bed of the Rutford Ice Stream in West Antarctica were also mapped (King et al., 2009), which is the only extant ice stream for which high resolution bed data are available (Table II; Figure 1(D)). Radar data were acquired perpendicular to flow and have an alongtrack spatial resolution of $7.5 \mathrm{~m}$, and a vertical resolution of $3 \mathrm{~m}$. Profiles were spaced at $500 \mathrm{~m}$ intervals in the along-flow direction and an interpolated surface was created using a 20-m-perpendicular-to-flow x 200-m-parallel-to-flow grid. This interpolation scheme maintains the continuity of features elongated in the flow direction, while preserving the high spatial sampling of the cross-flow bed profile. The surface representing the bed was then re-sampled at $50 \times 50 \mathrm{~m}$ spacing to form the digital terrain model used in this analysis. The data covers the lowermost portion of the Rutford Ice Stream, 25\% of its total area.

\section{Mapping techniques}

MSGLs were mapped from high-resolution bathymetric data (offshore), radar data (extant ice stream), and combined satellite images (onshore). Bathymetric and radar data were converted into digital terrain models and visualized as hill-shaded images with different illumination angles and elevations, as well as various vertical exaggerations, following a standardized method for mapping glacial bedforms (Smith and Clark, 2005). Due to a lack of similar high resolution digital terrain models onshore, MSGLs could only be mapped from satellite images. Improved identification of subtle landforms was achieved by using two different satellite sources and by (locally) stretching the contrast of these images. All landforms were mapped at a scale between 1:30 000 and 1:40 000, depending on the resolution of the terrain or satellite data.

Offshore and modern (Rutford) MSGLs are characterized by a continuous series of parallel crests separated by troughs or grooves. No evident breaks of slope are present to help delineate individual landform side-boundaries and MSGLs appear as a continuous rolling or waved surface, i.e. a sinusoidal profile in cross-section. Therefore, they were mapped as lines drawn along their crests (Figure 2(A)-(B)).

In all onshore settings, satellite images made it possible to identify MSGLs as individual features with distinct boundaries (Figure 2(C)-(D)) highlighted by shadows and by a change in colour which corresponds to a change in vegetation and soil moisture (corresponding to a break in slope). Onshore MSGLs were therefore mapped as both lines along their crests (to compare with the offshore data) and as elongate polygons.

\section{Measuring MSGLs}

The azimuth of all mapped MSGLs ( $\mathrm{n}=4043$ ) was automatically derived with specific GIS tools as the angle $\left(0-360^{\circ}\right)$ from grid North of each digitized line. Crestline length was evaluated from the total length of each MSGL crest line. Not all of the mapped MSGLs could be mapped for their entire extent (see also following section). These MSGLs were not included in the length analysis, which was therefore limited to a total of 3068 features. Width and elongation could only be extracted from the polygon data from onshore settings $(n=1929)$. Width was estimated using Euler's approximation for the width of an ellipse (Clark et al., 2009). Elongation was computed as length/width.

The across-flow spacing of MSGLs is the distance between adjacent crestlines. MSGLs are relatively long features, and some variation in lateral spacing along their extent has been noted. Therefore, multiple values (on each side) were regularly collected at $1 \mathrm{~km}$ intervals along each MSGL, by creating a series of $1 \mathrm{~km}$ spaced topographic profiles transverse to crestlines (Figure 3). The cross-profile interval represents a compromise between attempting to take multiple measurements along each individual MSGL and maintaining the time needed to process all data efficiently. With the $1 \mathrm{~km}$ cross-profile pacing, mean lateral spacing of MSGLs was obtained by typically averaging eight (four on each side) spacing values measured along individual MSGL. A semi-automated GIS procedure was then applied to determine the distance between adjacent crestlines along each profile (Figure 3). Two spacing measurements (i.e. the distance to each lateral neighbour) were collected at each interception point between a cross-profile and a MSGL crestline. Data were therefore summarized by calculating a mean MSGL spacing from these measurements. Only those MSGLs that had two adjacent neighbours (and that were not separated from these by large erosional features like meltwater channels or a field of iceberg furrows) were included in this analysis (1697 offshore and 1846 onshore). In addition, in order to assess how across-flow spacing varies downstream, a mean spacing was also determined for individual cross-flow profiles in the down-flow direction.

MSGL amplitude was defined as the difference between the elevation of the crestline and the lowest elevation recorded in the trough between adjacent MSGL crestlines on both sides of each MSGL (Figure 3). The same $1 \mathrm{~km}$ spaced cross-profiles used to measure spacing were employed for this task. The two amplitude values generated at each cross-profile interception point were averaged in order to produce a single value, an effective way to de-trend the variation in elevation due to the regional-scale topography. All intersection values were then averaged for each MSGL. Note, however, that amplitude could only be measured for the offshore MSGLs (for which a high resolution terrain model was available) and the same criteria were applied to dictate where spacing was measured $(n=1697)$. In order to assess how amplitude varies downstream, the mean amplitude was also determined for individual cross-flow profiles in the down-flow direction.

\section{Data fidelity}

MSGLs have likely experienced post-glacial modification. Attempts to quantify post-glacial erosion, current winnowing, glacimarine sediment draping, etc., are challenging and extremely rare (Kirshner et al., 2012; Finlayson, 2013). However, other modifications are easier to recognize (e.g. iceberg furrows, meltwater channels, etc.) and their influence on the derived metrics could be considerable. Where possible, these have been taken into account. For example, only fully imaged MSGLs (i.e. exclude those running off the edge of image domains) and those without a clear sign of being partly overridden (e.g. by moraine) or eroded (e.g. subsequent meltwater channel) were included in the length analysis. Similarly, spacing and amplitude were determined only for MSGLs showing continuity (i.e. no interruptions due to the presence of iceberg furrows or meltwater channels) between adjacent features.

The frequency distributions of MSGL metrics from different settings were assembled into single histograms (Figure 4). In 
order to avoid bias associated with settings with a greater number of measurements, the data were normalized according to the relative number of MSGLs of each setting.

\section{Results}

The metrics of the MSGL are presented in Table III for each study area and as an aggregated population for all mapped MSGLs. Statistics from each setting and normalized frequency histograms are shown in Figure 4.

MSGLs are characterized by lengths of up to $37 \mathrm{~km}$ and elongation ratios of up to 134:1 (Table I). However, although these maximum values have been commonly reported in previous work, they are not representative of the vast majority of sampled features. Moreover, these extreme values can strongly affect mean values, which also become unreliable statistical descriptors when frequency distributions are skewed, as is the case here. Consequently, a simpler and better way to describe their metrics is to focus on modal and median values and to provide a most common range, i.e. 10 and 90 percentiles.

\section{Parallel conformity}

The vast majority ( $80 \%$ ) of all studied MSGLs have an azimuth within $\mu$ (mean value) $\pm 5^{\circ}$, confirming the high level of parallel conformity described by many but rarely quantified (Clark, 1993). The narrowest azimuth distributions are found in Pine Island trough and on the Liard palaeo ice stream beds (all three with $80 \%$ of the population within just $5^{\circ}$ ). The broadest azimuth distributions (with a range of $18^{\circ}$ and $19^{\circ}$, respectively) are found in the Getz and Håkerringjdupet palaeo ice streams, where MSGLs are not straight but can be observed to bend, following a curving ice flow trajectory. However, even in these settings, the parallel conformity within adjacent MSGLs remains striking (Figure $1(\mathrm{D})$ ).

\section{Length, width and elongation}

For $80 \%$ of MSGLs, length is between 940 and 9050 m (with a mode of $1000-2000 \mathrm{~m}$ and median of $2890 \mathrm{~m}$ ). Frequency distributions of length for individual study areas are typically unimodal with a positive skew (i.e. a long, exponentially decreasing tail after the mode) and this can also be seen in the total population. Individual ice stream beds reveal median values ranging from $750 \mathrm{~m}$ (Håkerringjdupet) to $4480 \mathrm{~m}$ (Great Bear).

The vast majority $(80 \%)$ of MSGLs have widths of $90-720 \mathrm{~m}$ (mode 100-200 m and median $270 \mathrm{~m}$ ). The frequency distribution of all MSGLs is unimodal and positively skewed. Median widths for MSGLs varies from 90 (Cameron Hills) to $510 \mathrm{~m}$ (Great Bear).

Most (80\%) MSGLs have elongations between 6 and 33:1 (with a mode of 6-8:1 and median of 12:1). The frequency distribution of elongation is unimodal and positively skewed. For individual ice stream beds, median elongations vary from 10:1 (Great Bear and Haldane) to 25:1 (Liard).

\section{Spacing}

For $80 \%$ of MSGLs, their spacing is between 140 and $960 \mathrm{~m}$ (mode of $200-300 \mathrm{~m}$ and median of $330 \mathrm{~m}$ ). When all data are plotted in a single frequency histogram (bin width of $100 \mathrm{~m}$ ), the distribution is unimodal with a positive skew. Most individual ice stream beds are characterized by MSGLs spaced apart between $200 \mathrm{~m}$ and $400 \mathrm{~m}$, with the exception of the 

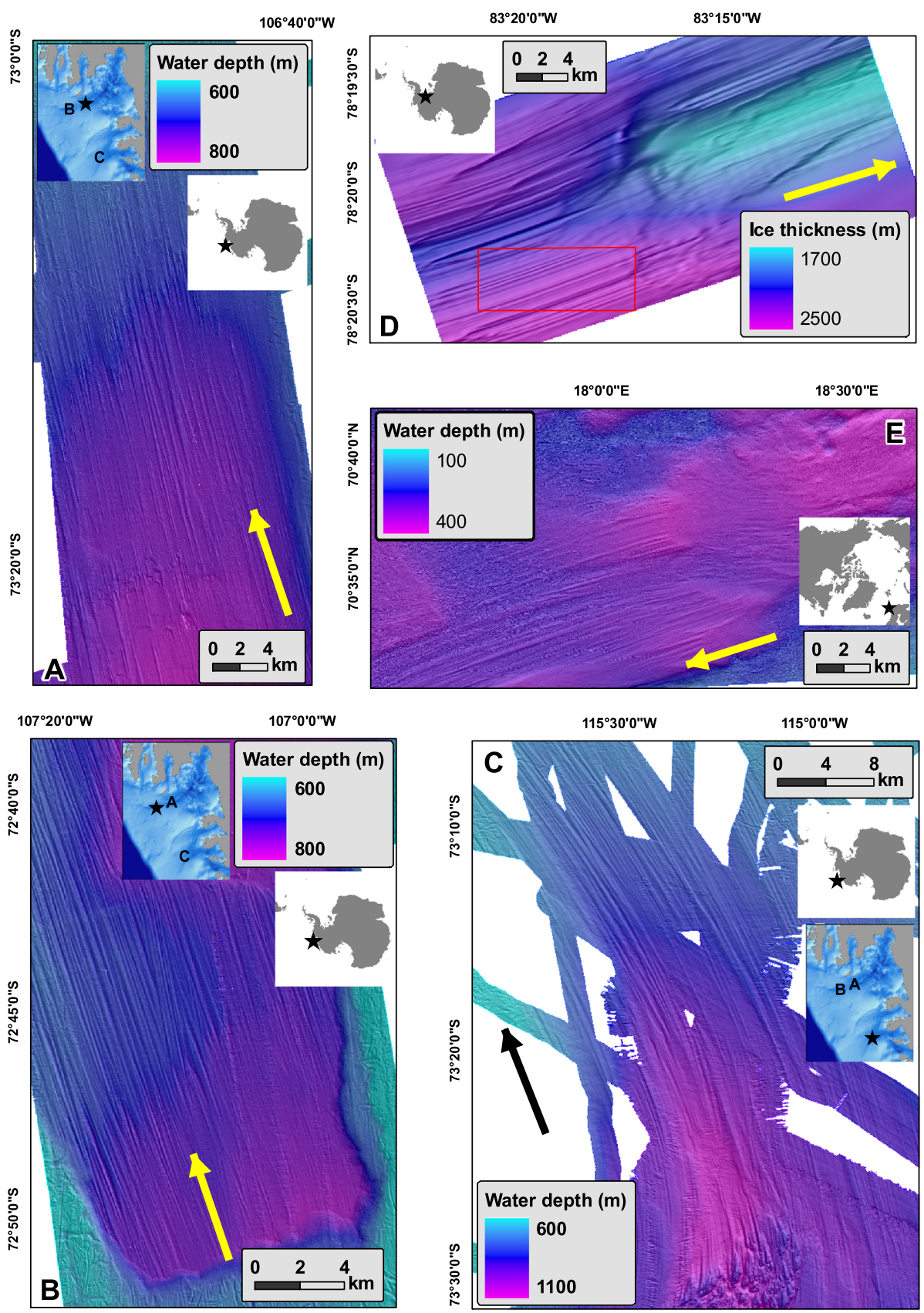

Figure 1. Overview of the ice stream beds analysed in this paper. A (letter codes refer to Table II): Pine Island S; B: Pine Island N; C: Getz; D: Rutford (the red box represents the area shown in Figure 3); E: Håkerringjdupet; I: Haldane; H: Liard; F: Great Bear; G: Cameron Hills. A, B, C and E are marine datasets, $\mathrm{D}$ is under existing ice stream and $\mathrm{I}-\mathrm{G}$ are terrestrial datasets. Terrain images hillshaded from various bathymetric and radar data (A-E). Satellite images from Landsat ETM + false colour $(4,3,2)$ composites with superimposed SPOT panchromatic band (I-G). Arrows show the direction of ice flow. This figure is available in colour online at wileyonlinelibrary.com/journal/espl

Great Bear palaeo ice stream bed where the median value is $840 \mathrm{~m}$. Over short distances $(1 \mathrm{~km})$, the spacing of most ice stream settings shows high variability in the downstream direction. However, over long distances (whole settings) four out of nine study areas show a statistically significant spacing trend (with a 99\% confidence interval) (Table IV; Figure 5) in the downstream direction. Of these, the Great Bear, Pine Island $\mathrm{N}$ and Getz MSGLs show decreasing mean spacing, while Haldane shows increased mean spacing moving downstream.

\section{Amplitude}

The vast majority (80\%) of MSGLs have amplitudes between $1 \mathrm{~m}$ and $9 \mathrm{~m}$ (with a mode of $1-2 \mathrm{~m}$ and median of $3 \mathrm{~m}$ ). The frequency distribution for all MSGLs is unimodal with a positive skew. While the Rutford Ice Stream bed shows a high median value of $8 \mathrm{~m}$, all other ice streams are characterized by a median amplitude between 2 and $3 \mathrm{~m}$. The downstream variation of mean amplitude is usually of the order of a few metres (Figure 5), with the exception of the sudden $10 \mathrm{~m}$ increase about $23 \mathrm{~km}$ downstream along the Rutford Ice Stream bed (Figure 5), likely related to the presence of a bedrock bump (King et al., 2009). Different ice streams reveal different trends (Table IV; Figure 5). The most statistically-significant trend is that of the Pine Island $\mathrm{N}$ ice stream bed, where MSGL amplitude shows a tendency to increase downstream. Other significant trends (within the $99 \%$ confidence interval) are those revealed by the Håkerringjdupet and Getz ice stream beds, the former showing increasing amplitude (and variability), while the latter shows decreasing amplitude downstream. It should also 

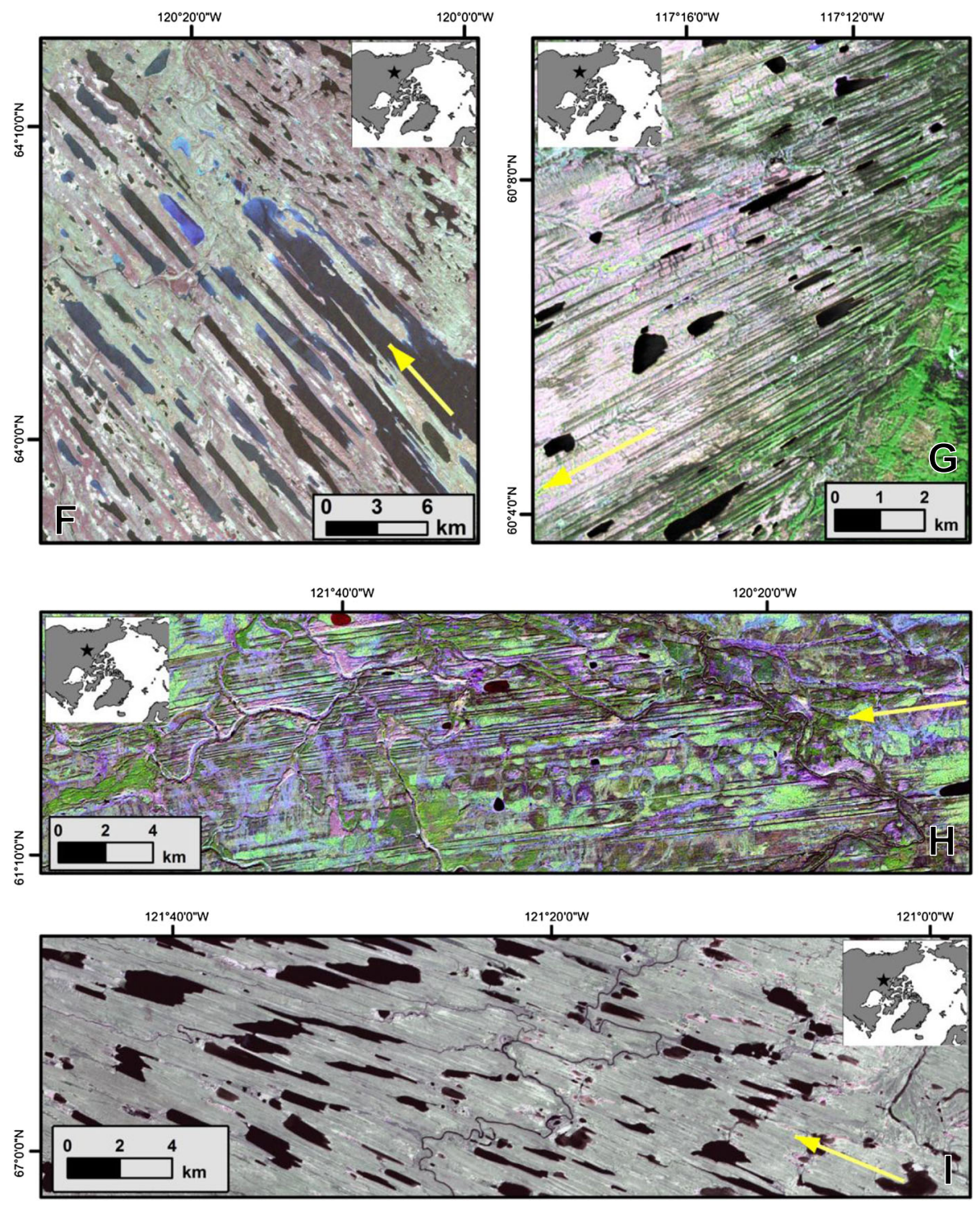

Figure 1. Continued

be noted that a trend of decreasing amplitudes exists before and after the bedrock bump (at $23 \mathrm{~km}$ ) on the Rutford Ice Stream bed (Figure 5).

\section{Discussion}

\section{Metrics}

Taken together, the metrics presented here quantitatively confirm MSGLs as kilometre-long, highly elongate features with amplitudes of only a few metres (mode of $1-2 \mathrm{~m}$ ) and a close and consistent spacing with a high parallel conformity. Their low amplitude and great length explains why MSGLs are typically not visible in the field and can only be fully appreciated and mapped from airborne and spaceborne imagery (Clark, 1993), or shipborne bathymetry.

\section{Consistency}

All measured variables show a unimodal distribution within each setting, thus indicating a prominent scaling preference rather than an even spread of values across a wide scale range or a multimodal distribution. Comparing distributions between ice stream settings reveals a strong consistency in the production of MSGLs of similar size, shape and spacing. With a few exceptions where local factors might have had an influence on specific metrics (e.g. Great Bear MSGL width), MSGL metrics were found to be very similar and always within the same order of magnitude. In some cases (e.g. spacing, Figure 5) the statistics are so strikingly close that there is virtually no difference between MSGLs from offshore Antarctica and onshore Arctic Canada. This is particularly remarkable because some of the settings are thousands of kilometres apart, and each was subjected to a specific glacial history (duration of flow, evolving ice thickness and velocity) and specific local topographic, sedimentary and lithological conditions. We interpret this consistency within and across the settings to indicate that MSGLs share a common origin, which is largely insensitive to local factors.

\section{MSGL length}

MSGLs are known for being extremely long features. The present study confirms this idea (maximum length $37 \mathrm{~km}$ ), but also scales down the proportions by indicating that the vast majority $(80 \%)$ of MSGLs are less than $9 \mathrm{~km}$ long (see also Stokes et al., 2013). This figure is almost one order of magnitude lower than reported in previous studies (Table I), although these often describe MSGLs by the maximum length measured within a field of MSGLs. This difference is also largely due to the fact that MSGLs have been mapped here in unprecedented detail, making it possible to identify and separate smaller features. Indeed, what generally appears to be a single feature at a small scale (e.g. 1:70 000), often reveals 

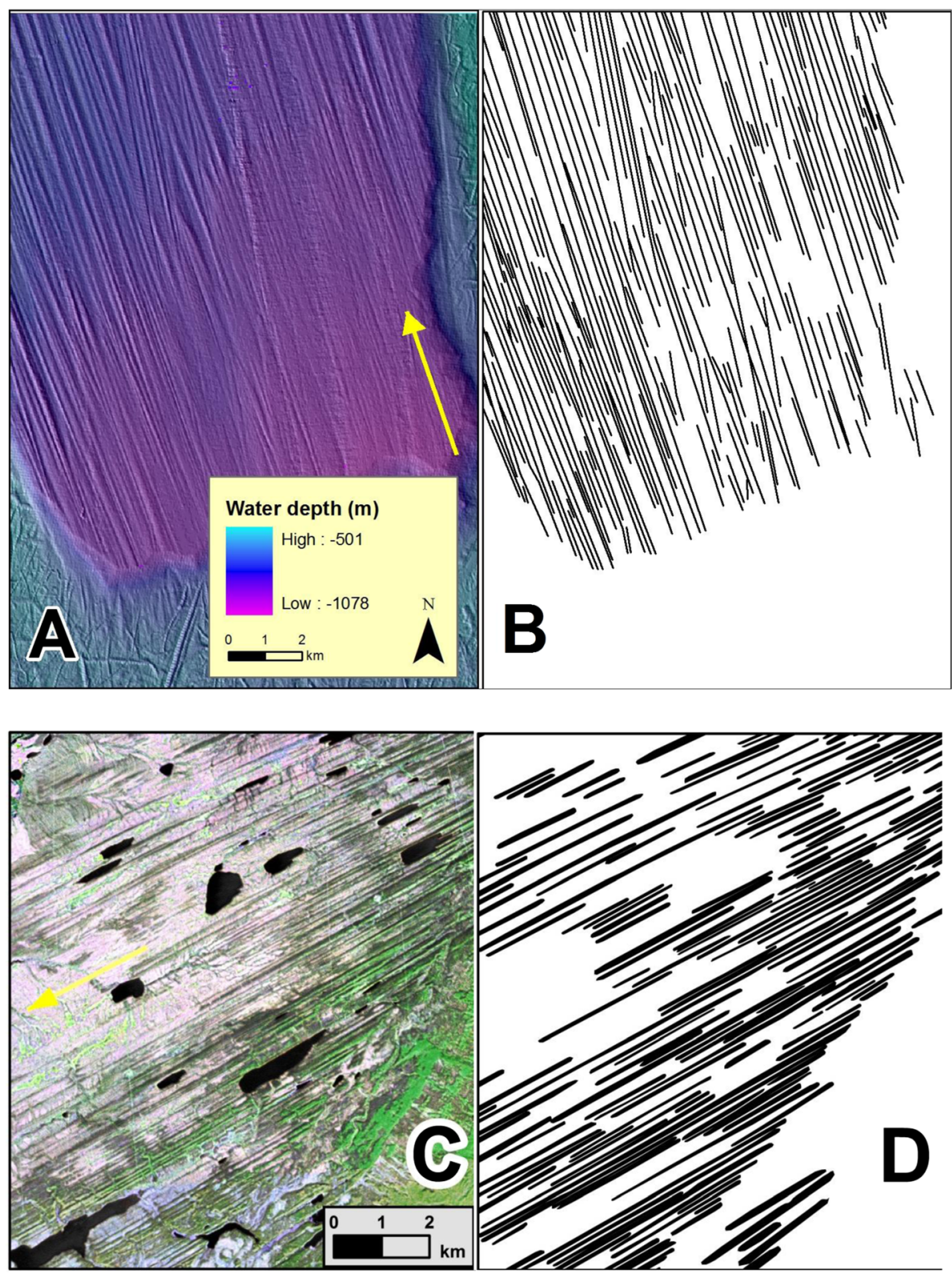

Figure 2. Examples illustrating the different mapping of MSGLs in different study areas that was dictated by the availability of imagery. Lines along the crests offshore (Pine Island Bay, A and B on the figure) and polygons onshore (Great Bear lce Stream, C and D on the figure). Arrows indicate the inferred palaeo direction of ice flow. This figure is available in colour online at wileyonlinelibrary.com/journal/espl

itself to be the sum of two or more aligned, but clearly-separated (by some tens of metres), landforms at a larger scale (e.g. 1:30 000).

A fundamental consequence of lineations sets extending up to hundreds of kilometres (Mosola and Anderson, 2006) and individual MSGLs being shorter than hitherto supposed is that multiple features exist at different downstream positions throughout the extent of an ice stream. In other words, individual MSGLs are not found to extend continuously throughout an ice stream bed, i.e. from its upstream to the downstream ends. Rather, they terminate and others initiate in multiple locations (Figure 7).

\section{Comparison with drumlins}

The length and the elongation of MSGLs are typically higher than drumlins (Clark et al., 2009), whereas the amplitude is about half as much as a typical drumlin relief (Spagnolo et al., 2012). However, other metrics, such as the width (compared with Clark et al., 2009) and the spacing are very similar to drumlins. In particular, the similarity in width but larger lengths are supportive of the argument that MSGLs could represent extremely elongate drumlins (Stokes and Clark, 2002) and that a similar mechanism might produce both MSGLs and drumlins, depending on the ice flow velocity (Clark, 1993; Stokes et al., 2013) and the nature and availability of sediment (Ó Cofaigh et al., 2005). Indeed, there are now many documented palaeo ice stream settings, both onshore (Stokes and Clark, 2002; Stokes et al., 2013) and offshore (Ó Cofaigh et al., 2002; Heroy and Anderson, 2005; Graham et al., 2009), where drumlins upstream become progressively more elongate and into MSGLs downstream, thus making a distinction between the two landforms very difficult.

Log-normal distributions

Like drumlins (Clark et al., 2009), the metrics of MSGLs show a unimodal frequency distribution with a positive skew. When length, amplitude or spacing for a population of MSGLs are converted into their natural logarithm and their frequency evaluated for bins of equal intervals (Figure 6), the resulting frequency distribution is log-normal, in common with drumlins (Fowler et al., 2013; Hillier et al., 2013). This type of distribution is frequent in nature, with examples from many disciplines, including geology and mining (e.g. concentration of elements), biology (e.g. 

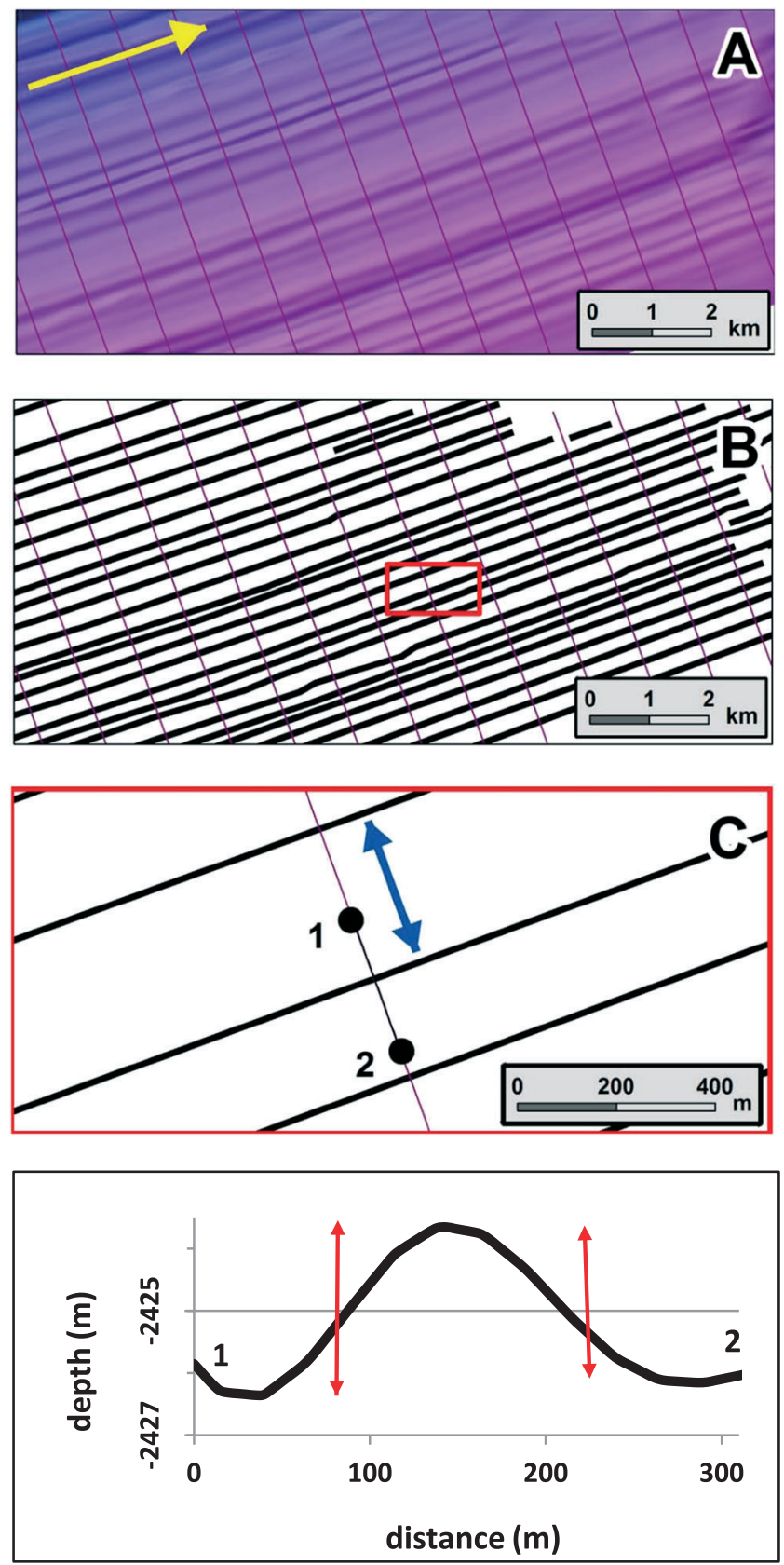

Figure 3. Spacing and amplitude determination using Rutford ice stream bed (see red box in Figure 1 for map overview). (A) hillshaded bathymetric data; the purple lines represent cross-sections spaced $1 \mathrm{~km}$ apart, while the yellow arrow indicates the direction of ice flow; colours refer to bathymetric scale of Fig. 2(A). (B) MSGLs mapped along their crestlines (black lines); red rectangle represents the area in C. (C) Blue arrow indicates MSGL spacing. Point 1 and 2 refer to the crosssection shown in D. (D) MSGL cross- section 1-2: red arrows indicate the amplitude measured as the difference in elevation between the crestline and adjacent low points in troughs (two values per MSGL). This figure is available in colour online at wileyonlinelibrary.com/journal/espl

airborne contamination by bacteria and fungi), human medicine (e.g. latency period of diseases) and ecology (e.g. species abundance) (Limpert et al., 2001 and references therein). Typically, log-normal distributions emerge from variables that are characterized by an incremental ('multiplicative') growth or fragmentation, but that initiated as a large number of independent events (Limpert et al., 2001). The log-normal distribution implies an element of randomness in the growth/decay of MSGLs, similar to that which has been advocated for ribbed moraines (Dunlop et al., 2008) and argued for drumlins (Fowler et al., 2013; Hillier et al.,
2013). In view of this, MSGLs are likely to represent a growing phenomenon for which the growth phases occur randomly, or for random durations, or under variably random physical conditions of the flow parameters (Hillier et al., 2013).

\section{Wider implications}

\section{MSGL formation theories}

The formation of MSGLs is enigmatic, despite their importance for understanding ice stream dynamics. Different formational hypotheses/ideas have been proposed, some invoking an erosional mechanism (Lemke, 1958) while others suggesting a constructional process (Bluemle et al., 1993), perhaps involving the deformation of subglacial sediment (Clark, 1993). Some advocate a prominent role for ice ploughing through sediment (Tulaczyk et al., 2001; Clark et al., 2003), while others consider water, either in terms of a mega-flood (Shaw et al., 2008) or a smaller film between ice and sediment that breaks down into a series of rills (Fowler, 2010). Currently, only two hypotheses provide testable, quantitative predictions about the morphometry of MSGLs with which we can compare our observations. These are the grooveploughing (Tulaczyk et al., 2001; Clark et al., 2003) and the rilling instability hypotheses (Fowler, 2010). The former suggests that MSGLs are the product of 'groove-ploughing', formed by a series of ice keels at the sole of the glacier. The keels would develop when streaming ice encounters a topographically rough area upstream (i.e. outcropping bedrock) or through lateral compression as the ice stream narrows through a convergent onset zone. The ice keels would then plough into soft, saturated sediments downstream for many kilometres, thereby producing grooves defining the MSGLs (Tulaczyk et al., 2001; Clark et al., 2003). MSGL formation would thus be considered as primarily erosional, although some sediment squeezing and deposition would be likely to occur in the intervening ridges between adjacent keels.

Our work highlights three main issues for the grooveploughing hypothesis to address. With the availability of higher resolution data it is apparent that individual MSGL initiate and terminate in various positions within an ice stream bed (Figure 7). This is instructive, as it implies that an individual MSGL can come into existence anywhere on the bed, contradicting the groove-ploughing expectations of the same ice keels surviving over very long distances (Tulaczyk et al., 2001).

In relation to the previous point, a second issue for the groove-ploughing hypothesis relates to the unimodal distributions of MSGL metrics (Figure 4). With some exceptions (e.g. outcrops of bedding planes), bedrock roughness is usually uneven across an ice stream bed and keels (and MSGLs) should therefore form at variable sizes. Large differences might be expected between outcrops of rocks from different settings. However, results indicate that, for the most part, MSGL size is relatively similar across various ice stream beds with different underlying geology. The same argument applies to MSGL spacing. Uneven outcropping should generate unevenly spaced keels (and MSGLs). However, results show that MSGL spacing varies relatively little within (and between) ice stream beds.

A further testable prediction of the groove-ploughing hypothesis is that ice keels should reduce in size while moving downstream as they melt because of frictional heat. A reduction of the size of the keel would therefore imply that groove depth should shallow and the groove width should widen in a downstream direction, with a corresponding increase in the spacing between adjacent lineations. The studied MSGLs extend for tens of kilometres and cover considerable portions of the original ice stream beds (see section Datasets). However, results indicate that across-flow spacing either shows no statistically significant downstream trend or, with the exception of the Haldane palaeo ice stream bed, 

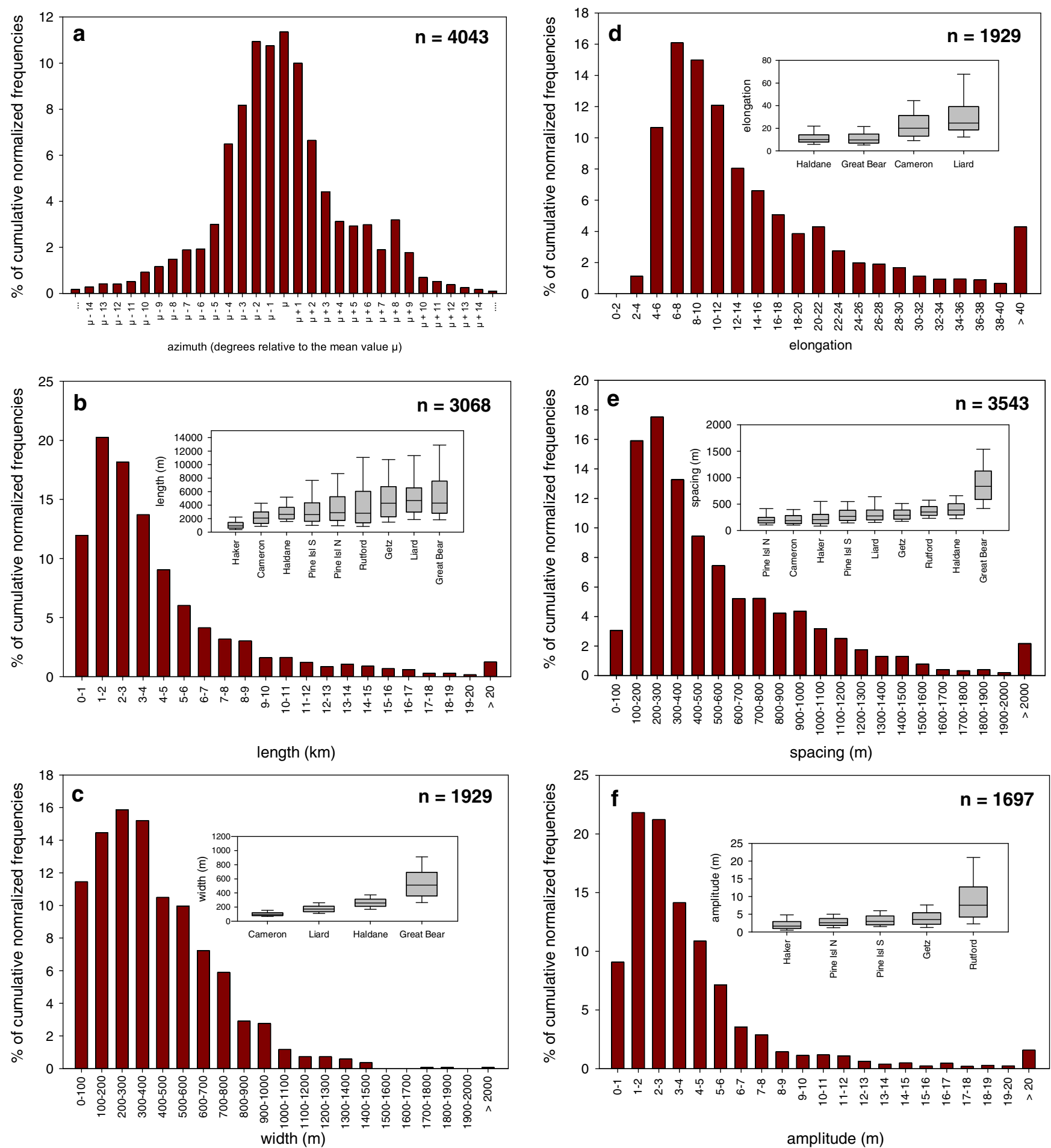

Figure 4. Frequency distribution of the azimuth (a), length (b), width (c), elongation (d), spacing (e) and amplitude (f) of all mapped MSGLs and statistical box plots for individual settings. The 5 percentile, 25 percentile, median, 75 percentile and 95 percentile are showed on the box plots. This figure is available in colour online at wileyonlinelibrary.com/journal/espl

consistently decreases in a downstream direction (Getz, Pine Island $\mathrm{N}$ and Great Bear palaeo ice stream beds). For amplitude, different ice streams reveal different trends or no trend. Those showing MSGL amplitudes decreasing downstream (e.g. parts of the Rutford Ice Stream and the Getz palaeo ice stream bed) are consistent with the groove-ploughing prediction; while those characterized by no evident trend (e.g. Pine Island S) or amplitudes increasing downstream (e.g. Håkerringjdupet and Pine Island $\mathrm{N}$ palaeo ice stream beds) are inconsistent. In its current form, therefore, the groove-ploughing hypothesis is mostly unable to account for our observations of MSGLs (see also ÓCofaigh et al., 2005).
The other hypothesis that provides quantitative predictions of the size and shape of MSGLs is that based on subglacial meltwater rilling (Fowler, 2010), which invokes an instability in an initially uniform water-film (typical value of $2.7 \mathrm{~mm}$ thick) flowing between the ice and the deformable subglacial till. Water-flow depth will be larger in an incipient stream, and this would allow faster flow and thus higher erosion and sediment transport. Consequently, the stream would deepen further, and this positive feedback, initiated by an instability, would result in the excavation of grooves, or rills, between ridges. The mathematical simulations suggest that the overlying ice would dampen the growth of the landform's height at relatively 


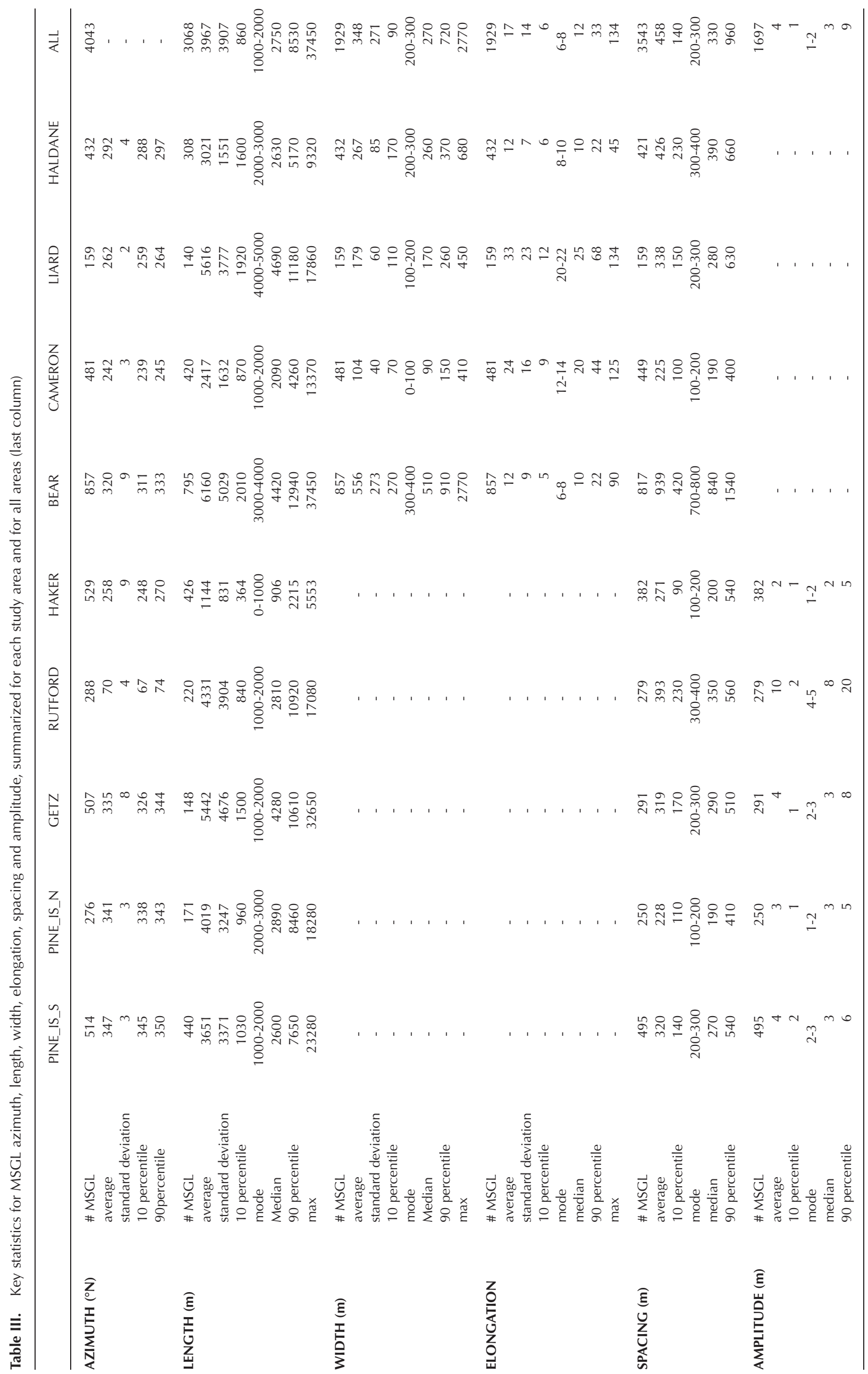


Table IV. Regression analysis of spacing and amplitude trends downflow.

\begin{tabular}{|c|c|c|c|c|c|c|c|c|c|}
\hline & PINE IS S & PINE IS N & GETZ & RUTFORD & HAKER & BEAR & CAMERON & LIARD & HALDANE \\
\hline $\begin{array}{l}\text { SPACING TREND } \\
\text { distance considered }(\mathrm{km}) \\
\text { slope of least squares fit-line } \\
\text { significance }\end{array}$ & $\begin{array}{l}38 \\
1.87 \\
0.0798\end{array}$ & $\begin{array}{l}31 \\
-2.77 \\
8.97 \mathrm{e}^{-05}\end{array}$ & $\begin{array}{l}35 \\
-3.08 \\
0.0013\end{array}$ & $\begin{array}{l}38 \\
1.55 \\
0.1583\end{array}$ & $\begin{array}{l}33 \\
9.98 \\
0.0112\end{array}$ & $\begin{array}{l}144 \\
-2.12 \\
3.19 \mathrm{e}^{-10}\end{array}$ & $\begin{array}{l}50 \\
0.77 \\
0.1953\end{array}$ & $\begin{array}{l}51 \\
-1.38 \\
0.4181\end{array}$ & $\begin{array}{l}42 \\
3.53 \\
0.0017\end{array}$ \\
\hline $\begin{array}{l}\text { AMPLITUDE TREND } \\
\text { distance considered }(\mathrm{km}) \\
\text { slope of least squares fit-line } \\
\text { significance }\end{array}$ & $\begin{array}{l}38 \\
0.01 \\
0.3785\end{array}$ & $\begin{array}{l}31 \\
0.04 \\
1.20 \mathrm{e}^{-06}\end{array}$ & $\begin{array}{l}35 \\
-0.05 \\
0.0005\end{array}$ & $\begin{array}{l}38 \\
0.07 \\
0.0202\end{array}$ & $\begin{array}{l}33 \\
0.13 \\
0.0016\end{array}$ & $\begin{array}{l}- \\
-\end{array}$ & $\begin{array}{l}- \\
-\end{array}$ & $\begin{array}{l}- \\
-\end{array}$ & $\begin{array}{l}- \\
-\end{array}$ \\
\hline
\end{tabular}
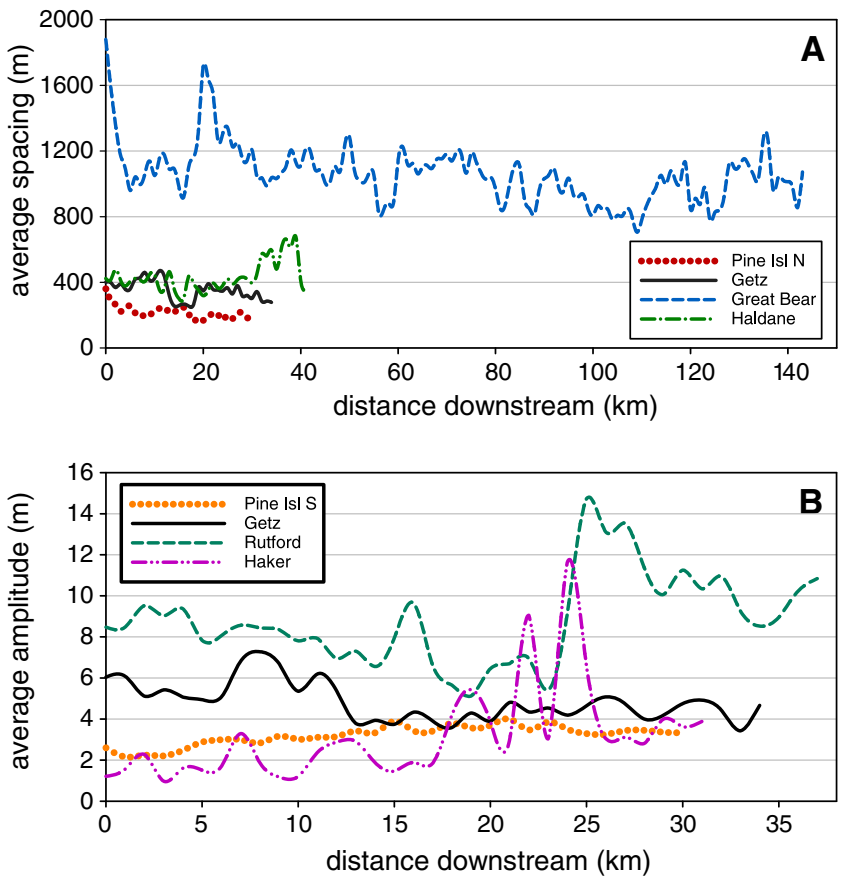

Figure 5. Downstream changes in MSGL mean spacing (A) and amplitude (B). Only settings showing statistically significant trends (as per Table IV) and/or discussed in the paper are shown. This figure is available in colour online at wileyonlinelibrary.com/journal/espl

short wavelengths $(12.3 \mathrm{~m})$, while maximum ( most common) growth of the length and the width would occur at relatively long wavelengths (52.9 $\mathrm{km}$ and $394 \mathrm{~m}$, respectively).

Our data show that most spacing values are between 200 and $300 \mathrm{~m}$, with lengths between 1 and $2 \mathrm{~km}$ and amplitudes from 1 to $2 \mathrm{~m}$. Thus, Fowler's (2010) predictions are overestimating both the length and amplitude of MSGLs, but the theoretical spacing is very close to observations and this hypothesis is yet to explore the full range of parameters. The hypothesis also suggests, implicitly, that MSGLs should be evenly spaced across an ice stream bed and this is indeed supported by the unimodal distribution of the across-flow spacing. A predominant spacing indicates that MSGLs tend to evenly occupy the available surface and could represent a spatially self-organized phenomenon, which is typical of instability-related bedforms (Clark, 2010). However, the data from this paper show that MSGLs initiate and terminate anywhere on the bed and this is not easily reconciled with rills forming where meltwater is expected to flow uninterrupted, unless changes in sediment properties are able to rapidly modify the character and pathway of meltwater flow on an ice stream.

In summary, an important implication of our quantitative data, therefore, is that current ideas and theories about MSGL formation are either un-supported or insufficiently developed (see also Stokes et al., 2013). Since MSGLs tend to evolve into
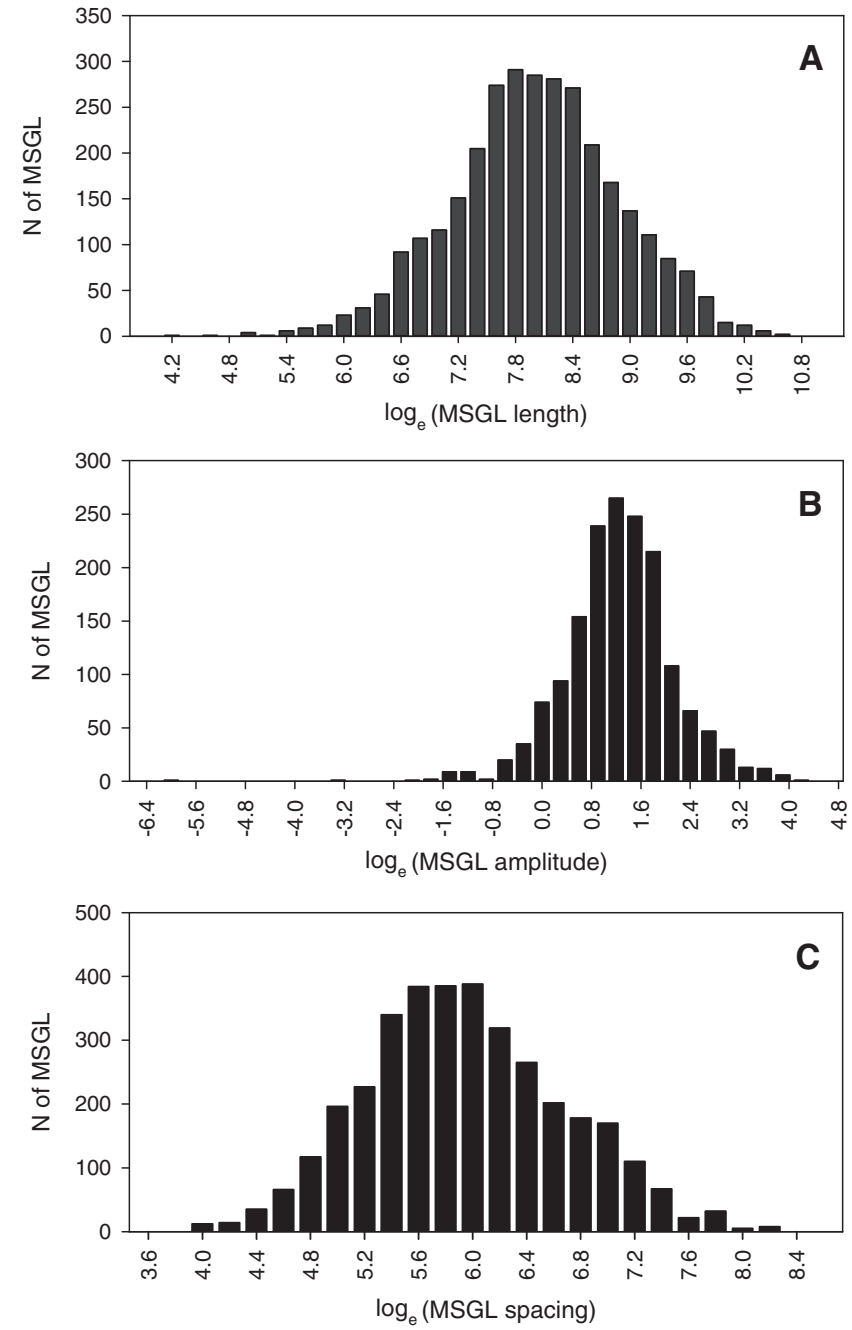

Figure 6. Log-normal frequency distribution of length (A), amplitude (B) and spacing (C).

a self-organized pattern (unimodal spacing distribution) and a dominant size and shape that is largely insensitive to local factors, it is plausible that some type of instability is governing their evolution, similarly to that which has been suggested for other glacial bedforms (Hindmarsh, 1998, 1999; Fowler, 2000). However, it is unclear at this stage if this would be the instability of the coupled ice and deforming bed invoked for drumlins, with MSGLs possibly representing elongate drumlins, or if it is an instability specific to the MSGL, such as the rilling one suggested by Fowler (2010), but which is not fully supported by the results presented in this paper.

MSGLs and ice stream flow mechanisms

Hydrological observations beneath the Whillans (B), Kamb (C) and Bindschadler (D) ice streams in Antarctica have suggested 
that the basal water pressure is very close to the ice overburden pressure, implying that it is plausible for the ice to flow via sliding over its bed (Engelhardt and Kamb, 1997; Kamb, 2001). The formation of MSGLs is compatible with ice stream sliding if these landforms are primarily formed by erosion, for example through a groove-ploughing mechanism (Tulaczyk et al., 2001; Clark et al., 2003) or in association with megafloods (Shaw et al., 2008). However, with regards to grooveploughing, the results presented here indicate that predictions from this hypothesis are not fully supported by observations. Issues have also been raised in relation to the mega-flood theory (Ó Cofaigh et al., 2005), among which that the volume of water required to form features occupying areas of thousands of square kms appears implausibly large (Ó Cofaigh et al., 2010; Shaw and Young, 2010) and recent investigations have recorded MSGLs being modified without any signs of concomitant megafloods (King et al., 2009), although strictly, this does not rule out floods having created them.

The notion that ice streams predominantly slide over their beds is, perhaps, also hard to reconcile with observations of trough mouth fans and grounding zone wedges deposited at ice stream grounding lines (Vorren and Laberg, 1997; Ó Cofaigh et al., 2003), which have always been assumed to reflect high sediment transport rates and a strong coupling between the base of the ice and the underlying sediment. Unless erosion occurs independently from ice streaming (Christoffersen et al., 2010) or an exceptional amount of (fine) sediment mobilization could be accounted for by the action of meltwater flowing in thin films, it is difficult to reconcile the deposition of large volumes of sediments with ice stream sliding. The alternative to sliding, which was traditionally advocated was that ice streams could largely (or entirely) move via subglacial sediment deformation, as supported by the discovery of several metres of fluted subglacial till with high porosity (i.e. likely to be dilated) beneath Whillans Ice Stream (Alley et al., 1986). Further theoretical and observational constraints have indicated that rapid fluctuations in ice stream velocity (for instance those observed on the Whillans Ice Stream) are indeed associated with variation in shear strain rate of the subglacial till (Tulaczyk, 2006). Under the scenario of ice flow being facilitated by sediment deformation, the ice would be coupled to its bed and the basal till would essentially be transported downstream with the flow of the ice, helping explain the advection of large volumes of sediment towards the grounding line of ice streams. MSGLs could evolve in this scenario either by net erosion or deposition or indeed both (redistribution of sediments). This is supported by observations of erosion and subsequent deposition beneath Rutford Ice Stream, where MSGLs have been seen to evolve (King et al., 2009; Smith and Murray, 2009); and by acoustic profiles that show MSGLs being part of an acoustically semi-transparent unit interpreted as deformation till (Dowdeswell et al., 2004). A further complication, however, is that recent studies have challenged the idea of a deep, pervasive, viscous shearing of the bed and observations from the Lake Michigan Lobe of the Laurentide Ice Sheet have suggested that the flow occurred there via shallow (decimetres) deformation of till patches (Thomason and Iverson, 2009; Iverson, 2010). Such a scenario is unlikely to promote spatially-continuous formation of MSGLs over hundreds of square kilometres and would require a series of build-up events in order to generate metres-tall features. Furthermore, the internal structure of some MSGLs has shown the presence of intact sedimentary bodies which are also hard to reconcile with pervasive deformation (Shaw et al., 2000; Ó Cofaigh et al., 2013). Taken together, these observations would suggest that MSGL formation takes place through a combination of sliding in the presence of near-overburden pressurized

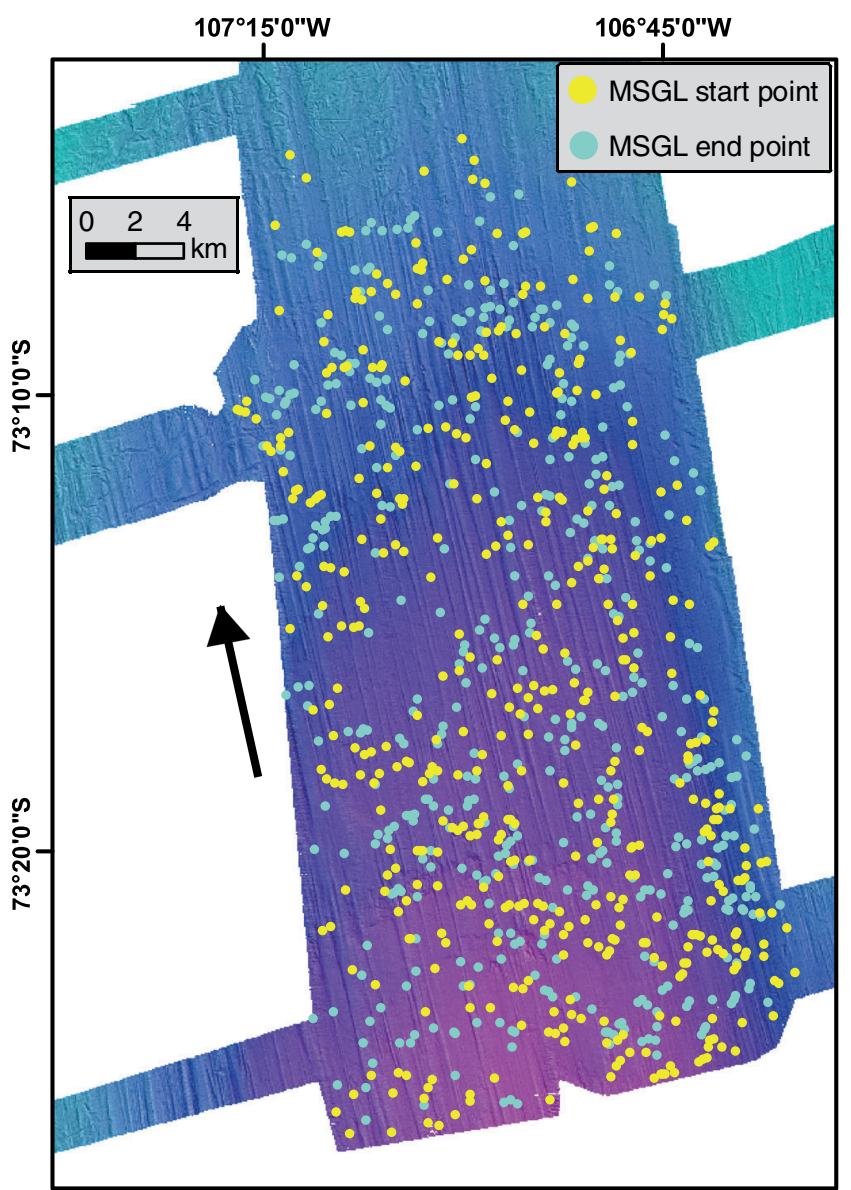

Figure 7. A map of the Pine Island $\mathrm{S}$ ice stream bed showing the location of MSGL start and end points as yellow and blue dots, respectively. The black arrow indicates the palaeo ice flow direction. This figure is available in colour online at wileyonlinelibrary.com/journal/espl

basal meltwater, with some sediment excavated/deformed and advected from in between and along ridges. The rilling instability theory (Fowler, 2010) appears to include most of these elements. However, our observations are only partially supportive of the theory's predictions in its present form.

\section{Conclusions}

The ice-bed interface is a key control on fast ice flow, with associated impacts on ice sheet mass balance and sea level. This is where mega-scale glacial lineations are formed and their study is likely to improve our understanding of ice stream dynamics. A number of hypotheses have been developed to explain the formation of MSGLs, but there is little agreement as to which might be correct, if any. In part, this reflects a lack of knowledge on their size, shape and spatial arrangement. This paper presents the first compilation of MSGL morphometries, allowing comparison between different ice stream beds, including both onshore and offshore, and palaeo and modern settings. Results suggest that MSGLs can be described as subglacial landforms characterized by a combination of considerable size (i.e. kilometres), especially length, with very subtle amplitudes (i.e. metres). Arguably, the most important and distinctive characteristic is their spatial arrangement, i.e. their consistent spacing and striking parallel conformity. Morphometric similarities within and between various settings are a clear indication that MSGLs are formed by the same mechanism, which is relatively insensitive to local conditions (topography, bedrock properties, etc.). 
Of the ideas pertaining to the formation of MSGLs, only a few provide explicit predictions of their shape and size. The results presented here are difficult to reconcile with some aspects of the groove-ploughing theory (Tulaczyk et al., 2001; Clark et al., 2003). Rather, MSGLs appear to reflect a self-organized (consistent spacing), probably growing (log-normal distribution of their metrics) phenomenon that tends towards a dominant size and shape, which hints at some sort of instability among the most likely ingredients for the formation of MSGLs. Whether this is the rilling instability invoked by Fowler (2010), whose predictions are only partially compatible with our observations, or the till instability invoked for the formation of drumlins (Hindmarsh, 1999; Fowler, 2000) remains to be seen. However, the present work represents a quantitative foundation which can serve as a test for any future development of theories of MSGL formation and, more widely, on the nature and behaviour of the ice-bed interface.

Acknowledgements—The authors would like to thank the editorial board of the journal as well as B. Davies and an anonymous reviewer for their positive and helpful feedbacks. Two reviewers of an initial version of this manuscript are also thanked as their comments and suggestions greatly improved the present paper. The authors would also like to thank Martin Jakobsson, Alexandra Kirshner, Monica Winsborrow and the Norwegian Hydrographic Service for providing access to some of the bathymetric data used in this paper. The research was funded by the NE/J004766/1 UK NERC New Investigator grant awarded to MS. The satellite images used in this project were downloaded from www.geobase.ca. JCE would like to thank the Denisons for funding his PhD.

\section{References}

Alley RB, Blankenship DD, Bentley CR, Rooney ST. 1986. Deformation of till beneath Ice Stream B, West Antarctica. Nature 322: 57-59.

Andreassen K, Winsborrow M. 2009. Signature of ice streaming in Bjørnøyrenna, Polar North Atlantic, through the Pleistocene and implications for ice-stream dynamics. Annals of Glaciology 50: 17-26.

Andreassen K, Nilssen LC, Rafaelsen B, Kuilman L. 2004. Three-dimensional seismic data from the Barents Sea margin reveal evidence of past ice streams and their dynamics. Geology 32: 729-732.

Andreassen K, Ødegaard CM, Rafaelsen B. 2007. Imprints of former ice streams, imaged and interpreted using industry three-dimensional seismic data from the south-western Barents Sea. Geological Society Special Publication 277: 151-169.

Andreassen K, Laberg JS, Vorren TO. 2008. Seafloor geomorphology of the SW Barents Sea and its glaci-dynamic implications. Geomorphology 97: 157-177.

Beget J. 1987. Low profile of the northwest Laurentide ice sheet. Arctic and Alpine Research 19: 81-88.

Bennett MR. 2003. Ice streams as the arteries of an ice sheet: their mechanics, stability and significance. Earth Science Reviews 61: 309-339.

Bluemle JP, Lord ML, Hunke NT. 1993. Exceptionally long, narrow drumlins formed in subglacial cavities, North Dakota. Boreas 22: 15-24.

Bougamont M, Price S, Christoffersen P, Payne AJ. 2011. Dynamic patterns of ice stream flow in a 3-D higher-order ice sheet model with plastic bed and simplified hydrology. Journal of Geophysical Research F: Earth Surface 116: F04018.

Brown VH, Stokes CR, Ó Cofaigh C. 2011. Glacial geomorphology of the north-west sector of the Laurentide ice sheet. Journal of Maps 2011: 409-428.

Canals M, Urgeles R, Calafat AM. 2000. Deep sea-floor evidence of past ice streams off the Antarctic Peninsula. Geology 28: 31-34.

Christoffersen P, Tulaczyk S, Behar A. 2010. Basal ice sequences in Antarctic ice stream: exposure of past hydrologic conditions and a principal mode of sediment transfer. Journal of Geophysical Research F: Earth Surface 115: F03034.

Clark CD. 1993. Mega-scale glacial lineations and cross-cutting iceflow landforms. Earth Surface Processes and Landforms 18: 1-29.
Clark CD. 1994. Large-scale ice-moulding: a discussion of genesis and glaciological significance. Sedimentary Geology 91: 253-268.

Clark CD. 2010. Emergent drumlins and their clones: from till dilatancy to flow instabilities. Journal of Glaciology 51: 1011-1025.

Clark CD, Tulaczyk SM, Stokes CR, Canals M. 2003. A groove-ploughing theory for the production of mega-scale glacial lineations, and implications for ice-stream mechanics. Journal of Glaciology 49: 240-256.

Clark CD, Hughes ALC, Greenwood SL, Spagnolo M, Ng FSL. 2009. Size and shape characteristics of drumlins, derived from a large sample, and associated scaling laws. Quaternary Science Reviews 28: 677-692.

Conway H, Hall BL, Denton GH, Gades AM, Waddington ED. 1999. Past and future grounding-line retreat of the West Antarctic ice sheet. Science 286: 280-283.

de Angelis H, Kleman J. 2005. Palaeo-ice streams in the northern Keewatin sector of the Laurentide ice sheet. Annals of Glaciology 42: 135-144.

Domack E, Amblas D, Gilbert R, Brachfeld S, Camerlenghi A, Rebesco M, Canals M, Urgeles R. 2006. Subglacial morphology and glacial evolution of the Palmer deep outlet system, Antarctic Peninsula. Geomorphology 75: 125-142.

Dowdeswell JA, Ó Cofaigh C, Pudsey CJ. 2004. Thickness and extent of the subglacial till layer beneath an Antarctic paleo-ice stream. Geology 32: 13-16.

Dunlop P, Clark CD, Hindmarsh RCA. 2008. Bed ribbing instability explanation: testing a numerical model of ribbed moraine formation arising from coupled ow of ice and subglacial sediment. Journal of Geophysical Research 113: F03005.

Engelhardt H, Kamb B. 1997. Basal hydraulic system of a West Antarctic ice stream: constraints from borehole observations. Journal of Glaciology 43: 207-230.

Engels JL, Edwards MH, Polyak L, Johnson PD. 2008. Seafloor evidence for ice shelf flow across the Alaska-Beaufort margin of the Arctic Ocean. Earth Surface Processes and Landforms 33: 1047-1063.

Evans J, Dowdeswell JA, Ó Cofaigh C. 2004. Late Quaternary submarine bedforms and ice-sheet flow in Gerlache Strait and on the adjacent continental shelf, Antarctic Peninsula. Journal of Quaternary Science 19: 397-407.

Evans J, Pudsey CJ, Ó Cofaigh C, Morris P, Domack E. 2005. Late Quaternary glacial history, flow dynamics and sedimentation along the eastern margin of the Antarctic Peninsula Ice Sheet. Quaternary Science Reviews 24: 741-774.

Evans J, Dowdeswell JA, Ó Cofaigh C, Benham TJ, Anderson JB. 2006 Extent and dynamics of the West Antarctic Ice Sheet on the outer continental shelf of Pine Island Bay during the last glaciation. Marine Geology 230: 53-72.

Finlayson A. 2013. Digital surface models are not always representative of former glacier beds: palaeoglaciological and geomorphological implications. Geomorphology 194: 25-33.

Fowler AC. 2000. An instability mechanism for drumlin formation. In Deformation of Glacial Materials, Maltman A, Hambrey MJ, Hubbard B (eds). Special Publication of the Geological Society 176. The Geological Society: London; 307-319.

Fowler AC. 2010. The formation of subglacial streams and mega-scale glacial lineations. Proceedings of the Royal Society of London Series A 466: 3181-3201.

Fowler AC, Spagnolo M, Clark CD, Stokes CR, Hughes ALC, Dunlop P. 2013. On the size and shape of drumlins. International Journal on Geomathematics 4: 155-165.

Graham AGC, Lonergan L, Stoker MS. 2007. Evidence for Late Pleistocene ice stream activity in the Witch Ground Basin, central North Sea, from 3D seismic reflection data. Quaternary Science Reviews 26: $627-643$.

Graham AGC, Larter RD, Gohl K, Hillenbrand C-D, Smith JA, Kuhn G. 2009. Bedform signature of a West Antarctic palaeo-ice stream reveals a multi-temporal record of flow and substrate control. Quaternary Science Reviews 28: 2774-2793.

Greenwood SL, Gyllencreutz R, Jakobsson M, Anderson JB. 2012. Iceflow switching and east/west Antarctic Ice Sheet roles in glaciation of the western Ross Sea. Geological Society of America Bulletin 124: 1736-1749.

Heroy DC, Anderson JB. 2005. Ice sheet extension on the Antarctic Peninsula during the last glacial maximum (LGM)-insights from 
glacial geomorphology. Geological Society of America Bulletin 117: 1497-1512.

Hess DP, Briner JP. 2009. Geospatial analysis of controls on subglacial bedform morphometry in the New York drumlin field - implications for Laurentide ice sheet dynamics. Earth Surface Processes and Landforms 34: 1126-1135.

Hillier JK, Smith MJ, Clark CD, Stokes CR, Spagnolo M. 2013. Size and shapes of subglacial bedforms reveal an exponential distribution. Geomorphology 190: 82-91.

Hindmarsh RCA. 1998. The stability of a viscous till sheet coupled with ice flow, considered at wavelengths less than the ice thickness. Journal of Glaciology 44: 285-292.

Hindmarsh RCA. 1999. Coupled ice-till dynamics and the seeding of drumlins and bedrock forms. Annals of Glaciology 28: 221-230.

Hubbard B, Milliken RE, Kargel JS, Limaye A, Souness C. 2011. Geomorphological characterization and interpretation of a midlatitude glacier-like form: Hellas Planitia, Mars. Icarus 211: 330-346.

Hulbe CL, Fahnestock MA. 2004. West Antarctic ice stream discharge variability: mechanism, controls, and pattern of grounding line retreat. Journal of Glaciology 50: 471-484.

IPCC. 2007. Changes and stability of ice sheets and ice shelves. In Contribution of Working Group I to the Fourth Assessment Report of the Intergovernmental Panel on Climate Change, Solomon S, et al. (eds). Cambridge University Press: Cambridge.

Iverson NR. 2010. Shear resistance and continuity of subglacial till: hydrology rules. Journal of Glaciology 56: 1104-1114.

Jakobsson M, Gardner JV, Vogt PR,Mayer LA, Armstrong A, Backman J, Brennan R, Calder B, Hall JK, Kraft B. 2005. Multibeam bathymetric and sediment profiler evidence for ice grounding on the Chukchi Borderland, Arctic Ocean. Quaternary Research 63: 150-160.

Jakobsson M, Anderson JB, Nitsche FO, Dowdeswell JA, Gyllencreutz R, Kirchner N, O'Regan MA, Alley RB, Anandakrishnan S, Mohammad R, Eriksson B, Fernandez R, Kirshner A, Minzoni R, Stolldorf T, Majewski W. 2011. Geological record of Ice Shelf Breakup and Grounding Line Retreat, Pine Island Bay, West Antarctica. Geology 39: 691-694.

Jakobsson M, Anderson JB, Nitsche FO, Gyllencreutz R, Kirshner AE, Kirchner N, O'Regan M, Mohammad R, Eriksson B. 2012. Ice sheet retreat dynamics inferred from glacial morphology of the central Pine Island Bay Trough, West Antarctica. Quaternary Science Reviews 38 : $1-10$.

Kamb B. 2001. Basal zone of the West Antarctic ice streams and its role in lubrication of their rapid motion. In The West Antarctic Ice Sheet: Behaviour and Environment, Alley RD, Bindschadler R (eds). Antarctic Research Series, 77. American Geophysical Union: Washington DC; 157-199.

King EC, Hindmarsh RCA, Stokes CR. 2009. Formation of mega-scale glacial lineations observed beneath a West Antarctic ice stream. Nature Geoscience 2: 585-588.

Kirshner AE, Anderson JB, Jakobsson M, O'Regan M, Majewski W, Nitsche FO. 2012. Post-LGM deglaciation in Pine Island Bay, West Antarctica. Quaternary Science Reviews 38: 11-26.

Larter RD, Graham AGC, Hillenbrand C-D, Smith JA, Gales JA. 2012. Late Quaternary grounded ice extent in the Filchner Trough, Weddell Sea, Antarctica: new marine geophysical evidence. Quaternary Science Reviews 53: 111-122.

Lemke RW. 1958. Narrow linear drumlins near Velva, North Dakota. American Journal of Science 256: 270-283.

Limpert E, Stahel WA, Abbt M. 2001. Log-normal distributions across the sciences: keys and clues. Bioscience 51: 341-352.

Livingstone SJ, Ó Cofaigh C, Stokes CR, Hillenbrand C-D, Vieli A, Jamieson SSR. 2012. Antarctic palaeo-ice streams. Earth-Science Reviews 111: 90-128.

Livingstone SJ, Ó Cofaigh C, Stokes CR, Hillenbrand C-D, Vieli A, Jamieson SSR. 2013. Glacial geomorphology of Marguerite Bay Palaeo-Ice Stream, western Antarctic Peninsula. Journal of Maps $\mathbf{9}$ : 558-572.

Lucchitta BK. 2001. Antarctic ice streams and outflow channels on. Geophysical Research Letters 28: 403-406.

McMullen K, Domack E, Leventer A, Olson C, Dunbar R, Brachfeld S. 2006. Glacial morphology and sediment formation in the Mertz Trough, East Antarctica. Palaeogeography Palaeoclimatology Palaeoecology 231: 169-180.
Moreau J, Ghienne JF, Le Heron DP, Rubino IL, Deynoux M. 2005. $440 \mathrm{Ma}$ ice stream in North Africa. Geology 33: 753-756.

Morgan VI, Jacka TH, Akerman GJ, Clarke AL. 1982. Outlet glacier and mass-budget studies in Enderby, Kemp and Mac. Robertson lands, Antarctica. Annals of Glaciology 3: 204-210.

Mosola AB, Anderson JB. 2006. Expansion and rapid retreat of the West Antarctic Ice Sheet in eastern Ross Sea: possible consequence of over extended ice streams? Quaternary Science Reviews 25: 2177-2196.

Nygård A, Sejrup HP, Haflidason H, Lekens WAH, Clark CD, Bigg GR. 2007. Extreme sediment and ice discharge from marine-based ice streams: new evidence from the North Sea. Geology 35: 395-398.

Ó Cofaigh C, Pudsey CJ, Dowdeswell JA, Morris P. 2002. Evolution of subglacial bedforms along a paleo-ice stream, Antarctic Peninsula continental shelf. Geophysical Research Letters 29: 41-1-41-4.

Ó Cofaigh C, Taylor J, Dowdeswell JA, Pudsey CJ. 2003. Palaeo-ice streams, trough mouth fans and high-latitude continental slope sedimentation. Boreas 32: 37-55.

ÓCofaigh C, Dowdeswell JA, Allen CS, Hiemstra JF, Pudsey CJ, Evans J, Evans DJA. 2005. Flow dynamics and till genesis associated with a marine-based Antarctic palaeo-ice stream. Quaternary Science Reviews 24: 709-740.

Ó Cofaigh C, Dowdeswell JA, King EC, Anderson JB, Clark CD, Evans DJA, Evans J, Hindmarsh RCA, Larter RD, Stokes CR. 2010. Comment on Shaw J, Pugin A, Young R. (2008): 'A meltwater origin for Antarctic shelf bedforms with special attention to megalineations', Geomorphology 102: 364-375. Geomorphology 117: 195-198.

Ó Cofaigh C, Stokes CR, Lian OB, Clark CD, Tulaczyk S. 2013. Formation of mega-scale glacial lineations on the Dubawnt Lake Ice Stream bed: 2. Sedimentology and stratigraphy. Quaternary Science Reviews 77: 210-227.

Ottesen D, Dowdeswell JA, Rise L. 2005a. Submarine landforms and the reconstruction of fast-flowing ice streams within a large Quaternary ice sheet: the $2500-\mathrm{km}-$ long Norwegian-Svalbard margin $\left(57^{\circ}-80^{\circ} \mathrm{N}\right)$. Geological Society of American Bulletin 117: 1033-1050.

Ottesen D, Rise L, Knies J, Olsen L, Henriksen S. 2005b. The Vestfjorden-Traenadjupet palaeo-ice stream drainage system, midNorwegian continental shelf. Marine Geology 218: 175-189.

Ottesen D, Dowdeswell JA, Landvik JY, Mienert J. 2007. Dynamics of the Late Weichselian ice sheet on Svalbard inferred from highresolution sea-floor morphology. Boreas 36: 286-306.

Ottesen D, Dowdeswell JA, Benn DI, Kristensen L, Christiansen HH, Christensen O, Hansen L, Lebesbye E, Forwick M, Vorren TO. 2008. Submarine landforms characteristic of glacier surges in two Spitsbergen fjords. Quaternary Science Review 27: 1583-1599.

Ottesen D, Stokes CR, Rise L, Olsen L. 2008b. Ice-sheet dynamics and ice streaming along the coastal parts of northern Norway. Quaternary Science Reviews 27: 922-940.

Polyak L, Edwards MH, Coakley BJ, Jakobsson M. 2001. Ice shelves in the Pleistocene Arctic Ocean inferred from glaciogenic deep-sea bedforms. Nature 410: 453-457.

Przybylski B. 2008. Geomorphic traces of a Weichselian ice stream in the Wielkopolska Lowland, western Poland. Boreas 37: 286-296.

Rebesco M, Liu Y, Camerlenghi A, Winsborrow M, Laberg JS, Caburlotto A, Diviacco P, Accettella D, Sauli C, Wardell N, Tomini I. 2011. Deglaciation of the western margin of the Barents Sea Ice Sheet - a swath bathymetric and sub-bottom seismic study from the Kveithola Trough. Marine Geology 279: 141-147.

Rignot E, Mouginot J, Scheuchl B. 2011. Ice flow of the Antarctic ice sheet. Science 333: 1427-1430.

Rise L, Sættem J, Fanavoll S, Thorsnes T, Ottesen D, Bøe R. 1999. Seabed pockmarks related to ${ }^{-}$uid migration from Mesozoic bedrock strata in the Skagerrak offshore Norway. Marine and Petroleum Geology 16: 619-631.

Ross M, Lajeunesse P, Kosar KGA. 2011. The subglacial record of northern Hudson Bay: insights into the Hudson Strait Ice Stream catchment. Boreas 40: 73-91.

Ruther DC, Mattingsdal R, Andreassen K, Forwick M, Husum K. 2011. Seismic architecture and sedimentology of a major grounding zone system deposited by the Bjørnøyrenna Ice Stream during Late Weichselian deglaciation. Quaternary Science Reviews 30: $2776-2792$.

Schoof C. 2002. Basal perturbations under ice streams: form drag and surface expression. Journal of Glaciology 48: 407-416. 
Schoof C, Clarke GKC. 2008. A model for spiral flows in basal ice and the formation of subglacial flutes based on a Reiner-Rivlin rheology for glacial ice. Journal of Geophysical Research 113: B05204.

Sejrup HP, Hjelstuen BO, Torbjorn Dahlgren KI, Haflidason H, Kuijpers A, Nygard A, Praeg D, Stoker MS, Vorren TO. 2005. Pleistocene glacial history of the NW European continental margin. Marine and Petroleum Geology 22: 1111-1129.

Shaw J, Young RR. 2010. Reply to comment by Ó Cofaigh, Dowdeswell, King, Anderson, Clark, DJA Evans, J. Evans, Hindmarsh, Lardner and Stokes 'Comments on Shaw J, Pugin A, Young R, (2009): A meltwater origin for Antarctic Shelf bedforms with special attention to megalineations.' Geomorphology 102: 364-375. Geomorphology 117: 199-201.

Shaw J, Faragini DM, Kvill DR, Rains BR. 2000. The Athabasca fluting field, Alberta, Canada: implications for the formation of large-scale fluting (erosional lineations). Quaternary Science Reviews 19: 959-980.

Shaw J, Pugin A, Young RR. 2008. A meltwater origin for Antarctic shelf bedforms with special attention to megalineations. Geomorphology 102: 364-375.

Shipp SS, Anderson JB, Domack E. 1999. Late Pleistocene-Holocene retreat of the West Antarctic Ice-Sheet system in the Ross Sea: Part 1 - geophysical results. Geological Society of America Bulletin 111: 1486-1516.

Smith MJ, Clark CD. 2005. Methods for the visualization of digital elevation models for landform mapping. Earth Surface Processing and Landforms 30: 885-900.

Smith AM, Murray T. 2009. Bedform topography and basal conditions beneath a fast-flowing West Antarctic ice stream. Quaternary Science Reviews 28: 584-596.

Smith AM, Murray T, Nicholls KW, Makinson K, Adalgeirsdóttir G, Behar AE, Vaughan DG. 2007. Rapid erosion, drumlin formation, and changing hydrology beneath an Antarctic ice stream. Geology 35: $127-130$

Spagnolo M, Clark CD, Hughes ALC, Dunlop P, Stokes CR. 2010. The planar shape of drumlins. Sedimentary Geology 232: 119-129.

Spagnolo M, Clark CD, Hughes ALC, Dunlop P. 2011. The topography of drumlins; assessing their long profile shape. Earth Surface Processes and Landforms 36: 790-804.

Spagnolo M, Clark CD, Hughes ALC. 2012. Drumlin relief. Geomorphology 153-154: 179-191.
Stoker M, Bradwell T. 2005. The Minch palaeo-ice stream, NW sector of the British-Irish Ice Sheet. Journal of the Geological Society 162: 425-428.

Stokes CR, Clark CD. 1999. Geomorphological criteria for identifying Pleistocene ice streams. Annals of Glaciology 28: 67-74.

Stokes CR, Clark CD. 2001. Palaeo-ice streams. Quaternary Science Reviews 20: 1437-1457.

Stokes CR, Clark CD. 2002. Are long subglacial bedforms indicative of fast ice flow? Boreas 31: 239-249.

Stokes CR, Clark CD. 2003. The Dubawnt Lake palaeo-ice stream: evidence for dynamic ice sheet behaviour on the Canadian Shield and insights regarding the controls on ice stream location and vigour. Boreas 32: 263-279.

Stokes CR, Spagnolo M, Clark CD, O'Cofaigh C, Lian OB, Dunstone RB. 2013. Formation of mega-scale glacial lineations on the Dubawnt Lake ice stream bed: 1 . size, shape and spacing from a large remote sensing dataset. Quaternary Science Reviews 77: 190-209.

Stolldorf T, Schenke H-W, Anderson JB. 2012. LGM ice sheet extent in the Weddell Sea: evidence for diachronous behavior of Antarctic Ice Sheets. Quaternary Science Reviews 48: 20-31.

Thomason JF, Iverson NR. 2009. Deformation of the Batestown Till of the Lake Michigan Lobe. Journal of Glaciology 55: 131-146.

Tulaczyk S. 2006. Scale independence of till rheology. Journal of Glaciology 52: 377-380.

Tulaczyk S, Scherer RP, Clark CD. 2001. A ploughing model for the origin of weak tills beneath ice streams: a qualitative treatment. Quaternary International 86: 59-70.

Vorren TO, Laberg JS. 1997. Trough mouth fans - palaeoclimate and ice-sheet monitors. Quaternary Science Reviews 16: 865-881.

Wellner JS, Lowe AL, Shipp SS, Anderson JB. 2001. Distribution of glacial geomorphic features on the Antarctic continental shelf and correlation with substrate: implications for ice behaviour. Journal of Glaciology 47: 397-411.

Wellner JS, Heroy DC, Anderson JB. 2006. The death mask of the Antarctic ice sheet: comparison of glacial geomorphic features across the continental shelf. Geomorphology 75: 157-171.

Winsborrow MCM, Clark CD, Stokes CR. 2004. Ice stream of the Laurentide Ice Sheet. Géographie Physique et Quaternaire 58: 269-280.

Winsborrow MCM, Clark CD, Stokes CR. 2010. What controls the location of ice streams? Earth-Science Reviews 103: 45-59.

Winsborrow MCM, Stokes CR, Andreassen K. 2012. Ice-stream flow switching during deglaciation of the southwestern Barents Sea. Geological Society of America Bulletin 124: 275-290. 